\title{
Probing the interfaces between the social sciences and social-ecological resilience: insights from integrative and hybrid perspectives in the social sciences
}

\author{
$\underline{\text { Samantha Stone-Jovicich }}^{1}$
}

\begin{abstract}
Social scientists, and scholars in related interdisciplinary fields, have critiqued resilience thinking's oversimplification of social dimensions of coupled social-ecological systems. Resilience scholars have countered with "where is the ecology" in social analyses? My aim is to contribute to current efforts to strengthen inter- and transdisciplinary debate and inquiry between the social-ecological resilience community and the social sciences. I synthesize three social science perspectives, which stress the complex, dynamic, and multiscalar interconnections between the biophysical and social realms in explaining social-environmental change, and which place both the social and ecology centre stage in their analyses: materio-spatial world systems analysis, critical realist political ecology, and actor-network theory. By integrating, in a nondeterministic and nonessentialist manner, the biophysical environment into social inquiries (integrative approaches) or by altogether abolishing the ecology/nature and human/culture divide (hybrid perspectives), these three social-science perspectives are well placed to foster stronger inter- and transdisciplinary ties with social-ecological resilience. Materiospatial world systems analysis is highly compatible with resilience thinking. The emphasis on world systems structures and processes offers the potential to enrich resilience analyses of global environmental change, global governance and stewardship, planetary boundaries, and multiscale resilience. Critical realist political ecology offers avenues for more in-depth interdisciplinary inquiries around local/traditional/indigenous knowledge systems and power. It also challenges resilience scholars to incorporate critical analyses of resilience's core concepts and practices. Actor-network theory proposes a very different starting point for understanding and assessing social-ecological resilience. Its focus on "resilience-in-the-making" offers unique insights but also pushes the conceptual boundaries of resilience thinking.
\end{abstract}

Key Words: actor-network theory; agency; ANT; human-environment relations; hybrid perspectives; interdisciplinary; normative issues; political ecology; power; social-ecological resilience; social-ecological systems; social sciences; social systems; transdisciplinary; world systems analysis

\section{INTRODUCTION}

Resilience ideas, i.e., resilience thinking (Walker and Salt 2006) and practice (Walker and Salt 2012, Brown 2014), have contributed significantly to breaking down the simplistic dualistic and static view of nature and society and to opening innovative pathways for addressing pressing environmental issues. Socialecological resilience approaches, in particular, pay explicit attention to the synergies, interdependencies, and dynamics between human and environmental subsystems in socialecological systems (SESs; Folke et al. 2003, Gunderson et al. 2005) and acknowledge the pervasiveness of humans in ecosystems (Folke et al. 2004, Trosper 2005). Nonetheless, resilience's conceptualization of the social sphere has triggered some serious questioning among social scientists and scholars in related fields such as planning theory and practice. The main concern raised is that social dimensions and relations in coupled SESs are generally approached from a narrow topical and theoretical lens (Nelson et al. 2007, Leach 2008, Turner 2008, 2010, Davidson 2010, Leach et al. 2010, Miller et al. 2010, Brown and Westaway 2011, Armitage et al. 2012, Cote and Nightingale 2012, Davoudi et al. 2012). Among the critiques is that resilience thinking's view of the "social" is overridden by ecological understandings of system characteristics and dynamics (Nadasdy 2007, Hornborg 2009, Norgaard 2010, Simmie and Martin 2010, Turner 2010). Davidson (2010) and Cote and Nightingale (2012) argue that this effectively results in dimensions that are unique to social systems, such as historic and place-specific cultural and political contingencies, human agency, and normative issues, being largely overlooked. Others, such as Hatt (2013), take a different perspective arguing that although SESs and their ecological subsystems are treated as dynamic, adaptive, and characterized by multiequilibria, social systems tend to be viewed through a more conservative lens in which structures, functions, and order are emphasized.

In response to these critiques, resilience scholars, whom I loosely define as researchers who engage with social-ecological resilience ideas in their work, have pointed to the extensive scholarship on local and traditional knowledge (Folke 2004, Moller et al. 2004, Gömez-Baggethun et al. 2012, Bohensky et al. 2013, Ruiz-Mallén and Corbera 2013, Walsh et al. 2013, Reyes-García et al. 2014); spiritual, inspirational, and aesthetic services and culture (Long et al. 2003, Trosper 2005, Berkes et al. 2009, Chapin 2009, Crane 2010, Crona et al. 2013, Forbes 2013); mental models (Jones et al. 2011, Stone-Jovicich et al. 2011, Lynam et al. 2012, Moloney et al. 2014); well-being (Armitage et al. 2012); power relations (Ahlborg and Nightingale 2012, Ratner et al. 2013, Vink et al. 2013); innovation (Biggs et al. 2010, Moore and Westley 2011, Leach et al. 2012, Westley 2013); leadership (Olsson et al. 2006, Stephenson 2011, Westley et al. 2013); social networks (Crona and Hubacek 2010, Moore and Westley 2011, Rathwell and Peterson 2012); institutional analyses (Anderies et al. 2004, Lebel et al. 2006); learning (Davidson-Hunt and Berkes 2003, Lundholm and Plummer 2010, Roux et al. 2011, Pahl-Wostl et al. 2013); and adaptive governance and comanagement (Folke et al. 
2005, Olsson et al. 2006, Plummer and Armitage 2007, Kofinas 2009, Galaz 2012, Gupta and Pahl-Wostl 2013a, b, Baird et al. 2014). They also have challenged social scientists to consider more explicitly "where is the ecology?" in social analyses (see, for example, Peterson 2000).

The concerns and questions raised by both resilience scholars and social scientists are, at their base, reflections of very old and enduring tensions and debates within and across the natural and social sciences (see Ivakhiv 2002, Glaser 2006, Catton 2012, Barry and Born 2013). In this latest round of the debate, neither camp is entirely right or wrong. In earlier work, resilience approaches to the social leaned toward structural functionalist analyses that conceived social systems as a set of components, e.g., economic structures, institutions, norms, cultures, and knowledge systems that are interlocked functionally to minimize instability (see discussion by Hatt 2013). For example, Adger et al. (2005:1036, as cited by Hatt 2013; emphasis added) defined social-ecological resilience as "the capacity of social-ecological systems to absorb recurrent disturbances (...) so as to retain essential structures, processes, and feedbacks." Resilience inquiries have since broadened both their theoretical lens and methodological toolkit as evidenced by the range of topics and disciplinary contributions in articles published in Ecology and Society and elsewhere (e.g. Westley et al. 2002, West et al. 2014). Moreover, the boundaries between resilience scholars and those engaged in other traditions of human-environment research are at times blurry. For example, economists Kenneth Arrow and Steve Polasky, political scientist Elinor Ostrom, and geographer and land-change scientist Billie L. Turner II, are not necessarily regarded, or may not label themselves, as resilience scholars. However, they are among a number of scholars who have made significant social science and interdisciplinary contributions to resilience thinking. Nonetheless, there remain some relatively unexplored areas in the resilience scholarship, notably the role of human actors and agency; the interplay among diverse framings, discourses, and values; and issues of power, politics, and conflict in driving change and shaping complexity in coupled social-ecological systems (see Lélé 1998, Nadasky 2007, Leach 2008, Hornborg 2009, Davidson 2010, Brown and Westaway 2011, Evans 2011, Armitage et al. 2012, Hatt 2013, Brown 2014, West et al. 2014).

The social sciences too have debated about how to incorporate the biophysical world into their theoretical frameworks, inquiries, and analyses (in the case of sociology, for example, see Carolan 2005, Dunlap and Marshall 2007, Catton 2012). These discussions have played out across an extensive and rich social scholarship around human-environment/nature-society interactions, much of which precedes the emergence of interdisciplinary fields and concepts such as social-ecological resilience, social-ecological systems (SES), coupled human-environment systems (CHES), and coupled human and natural systems (CHANS). Conventional social science and behavioral disciplines, i.e., anthropology, sociology, political sciences, human geography, psychology, and economics, have greatly varied in how they have engaged with the biophysical realm. This has ranged from earlier environmental deterministic perspectives (e.g., Huntington 1915) to more recent postmodernist accounts of nature, which posit environmental problems as entirely socially constructed (e.g., White 1998). In the last quarter of the twentieth century, environmental subfields in the social sciences (such as ecological anthropology, environmental sociology, and ecological/ environmental economics) and environmental multi-, inter-, and transdisciplinary fields (e.g., sustainability science, land-change science, and global change science) have pushed the debate and scholarship beyond solely bio- or socio-centric approaches to perspectives that highlight the relational, interactive, or dialectic relationships between nature and society (for an expansion on this point see Ivakhiv 2002). I look at a subset of this body of scholarship, focusing on three specific streams of work that originated in the social sciences. These are: materio-spatial world systems analysis, critical realist political ecology, and actornetwork theory. What unifies these approaches is either an integration, in a nondeterministic and nonessentialist manner, of the biophysical environment into social analyses, which I call integrative approaches, or the abolishment of the ecology/nature and human/society/culture divide, i.e., hybrid perspectives.

My aim is twofold. The first is to draw attention to a subset of scholarship within the social sciences that explicitly incorporates the ecosystem and biophysical entities as important drivers of social-environmental change. The second aim is to contribute to current efforts to strengthen inter- and transdisciplinary debate and inquiry between the resilience community and the social sciences. To do so, I begin with an overview of how the social sciences have engaged with ecological dimensions, focusing on ecologically integrative and hybrid perspectives. This is followed by brief overviews of materio-spatial world systems analysis, critical realist political ecology, and actor-network theory. I then explore how these three perspectives have the potential to inform as well as challenge resilience thinking. In focusing on schools of thought from the social sciences, the intention is not to reinforce disciplinary boundaries or elevate any particular body of knowledge. The three perspectives discussed represent only a small subset of a broader and very diverse array of humanenvironment perspectives that offer resilience considerable insights in their own right (such as land-change science, e.g., Turner et al. 2007; and constructivist approaches, see Leach 2008, West et al. 2014). This is also true of natural and social science traditions that focus exclusively on biophysical or social dimensions. I thus share Zimmerer and Bassett's (2003:276) view that interdisciplinary efforts "[in the field of resilience] must be accompanied by disciplinary depth and [aim for] rigorous transdisciplinary synthesis." My choice to focus on these three specific perspectives was motivated by the fact that they remain relatively unexplored in the social-ecological resilience literature. An additional consideration was that they take a complex view of the relationship between the biophysical and social worlds: the former is not treated as a mere input into social systems but as entities and forces that are intricately linked with, and shape, humans and social life.

I would like to highlight that this is primarily a synthesis and reflective piece; it does not offer exhaustive reviews or propose alternative frameworks. It is essentially explorative and intended for readers who share an interest in probing the interfaces between social science theoretical perspectives and social-ecological resilience. The three social science perspectives selected and resilience thinking are each underpinned by different ontologies and epistemologies and, with that, comes both incompatibilities and prospects for new and creative ideas. My hope is to sow the seeds for novel inter- and transdisciplinary thinking about the 
dynamics and complexities of social-ecological change that can contribute to new pathways for tackling the global environmental challenges that face us.

\section{ECOLOGY AND THE SOCIAL SCIENCES: INTEGRATIVE AND HYBRID PERSPECTIVES IN THE SOCIAL SCIENCES}

Social science perspectives on the relationships and dynamics between people and the biophysical world are wide ranging. Differences emerge primarily from divergent philosophical assumptions about what constitutes reality (i.e., ontology) and what counts as knowledge and what can be known (i.e., epistemology; see Evely et al. 2008, Moon and Blackman 2014). As such, there is significant and in some instances intractable contestation around whether and how ecological systems, or the biophysical world, should be integrated into social theories, frameworks, and analyses. Space limits me from delving into these in more detail, but there are numerous overviews of the compatibilities and tensions among the diversity of naturehuman perspectives in the social sciences (for example, with regards to sociology, see Woodgate and Redclift 1998, Belsky 2002, Buttel 2002, White 2006, Dunlap and Marshall 2007, McLaughlin and Dietz 2008, Mol 2010, Catton 2012). Over the past two decades, in partial reaction to some strands of constructivism and to postmodernist perspectives, a contingent of social scientists have argued for bringing nature back in the social sciences (Catton 1992) and for "more engagement with ecological theory and ecological processes as they articulate with social processes in contingent, dynamic ways" (Nightingale 2002:1; see also Ivakhiv 2002, Zimmerer 2003, Carolan 2005, White 2006, Whatmore 2013).

Social scientists have responded to this call in multiple ways. One approach has been to integrate biophysical dimensions into existing social theoretical frameworks. Through empirical studies, these studies delineate the complex and dynamic ways in which diverse nonhuman and human dimensions of our world, each with their unique characteristics and dynamics, contingently and recursively drive and shape each other. For lack of a better word, I call these "integrative" approaches. In contrast to "hybrid" perspectives, an ontological and conceptual separation of the social and nonhuman biophysical worlds is retained. Examples of such scholarship include Norgaard's (1984) concept of coevolution, Bunker's $(1985,2003)$ and Bunker and Ciccantell's (1999) materio-spatial world systems/new historical materialist approach, Nauser and Steiner's (1993) human ecology, Crumley's (1994) historical ecology, Woodgate and Redclift's (1998) coevolution/social construction framework, Escobar's (1999) antiessentialist political ecology, Forsyth's (2001, 2003) and Forsyth and Evans' (2013) critical realist political ecology, Prew's (2003) notion of world-ecosystem, and Carolan's (2005) ecologically embedded sociology (regarding the nature-human dualism underpinning some of these works, see Ivakhiv 2002). Much of the postpositivist traditions in environmental subfields of the social sciences, e.g., ecological/environmental economics, and interdisciplinary fields, such as sustainability science, landchange sciences, global-change sciences, natural-hazards research, and vulnerability studies, can also be said to generally adopt an integrative approach (e.g., Burton et al. 1978, Ostrom 1990, Blaikie et al. 1994, Turner et al. 2003, 2007, Sen 2004, Clark 2007, Dasgupta 2010, Kates 2011, Levin et al. 2013).
Another strand of social science scholarship has adopted hybrid perspectives that attempt to blur the lines between the "social" and "nature" (see Albertsen and Diken 2006, as cited in Dolwick 2009, Barry and Born 2013, Rudy and White 2014). The terms hybrid and hybridity have a long and complex history and have been applied across a variety of conceptualizations of the relationship between humans, the social sphere, and the biophysical environment (see Braun and Castree 1998, Curry et al. 2012, Rudy and White 2014). For example, political ecologist Piers Blaikie's research has been referred to as hybrid because of its effort to reach across social and biophysical domains (see Rocheleau 2008). In its strictest sense, however, hybrid science refers to theoretical strands that reject the dualist categories of human/culture/society and environment/ecology/nature (Ivakhiv 2002, Rudy and White 2014). It highlights the role of nonhumans in shaping social life. To overcome "the modern constitution whereby nature is over there and society is around here and never the twain shall meet" (Rudy and White 2014:124), this scholarship typically adopts metaphors such as actor-networks, natureculture hybrids, quasi-objects (Latour 1993), assemblages (Latour 1996), hybrid collectif (Callon and Law 1995), cyborgs (Haraway 1991), and rhizomes (Deleuze and Guattari 1980), among others. Rudy and White (2014) credit Bruno Latour and Donna Haraway, both Science and Technology Studies scholars, as the pioneers of the discussion and application of hybridity in the natural and social sciences over the past couple of decades. Latour's actornetwork theory (1993, 1996, 2005), Haraway's (1991) cyborgs, and Whatmore's (2002, 2008) more-than-human and hybrid geography are examples of hybrid perspectives coming from the social sciences.

I first review two integrative perspectives: materio-spatial world systems analysis and critical realist political ecology. I follow this with a synthesis of actor-network theory, a hybrid perspective. All three perspectives share with social-ecological resilience thinking a focus on the interdependent and dynamic ways in which the biophysical and social shape our world. This mutual interest makes them particularly promising for fostering stronger interand transdisciplinary ties with resilience.

\section{MATERIO-SPATIAL WORLD SYSTEMS ANALYSIS: BRINGING IN ECOLOGY}

World systems analysis or theory has been around for a long time, first articulated by sociologist Immanuel Wallerstein (1974) and his colleagues. Today, it encompasses a diversity of approaches and empirical studies, which span a range of social science disciplines including history, sociology, anthropology, economics, and development studies (Chase-Dunn and Lawrence 2010, Hall 2000). World systems analysis (WSA) mainly focuses on the emergence and dynamics of the capitalist world political economy over the past 500 years, which is argued to be the first social system in human history to extend across the planet (Wallerstein 2000). The main premise is that studying world system level processes and patterns are important for understanding long-term and cross-scale society-environment relations and dynamics (ChaseDunn and Grimes 1995). As noted by Chase-Dunn and Lawrence (2010), there are very few other approaches in the social sciences that provide such a global level analytical lens. This macroscale focus does not negate the importance of studying processes at smaller scales, be they regions, nations, or communities. However, focusing singularly on the internal dynamics of particular 
societies or localities is viewed by world systems approaches as insufficient to explain dynamics of change (Mauro 2009). The underlying assumption, embedded in the notion of world system, is that the contemporary world is so interconnected that it constitutes a whole interactive system, i.e., the global and local, and everything in between, are intricately tied to each other (Chase-Dunn and Grimes 1995). As such, social-environmental dynamics, and by extension inequities and ecological degradation, cannot be adequately understood by focusing on one scale alone (Hall 2000). This multiscalar, systems perspective is well aligned with resilience thinking, particularly with the notion of panarchy (Gunderson and Holling 2002). However, with the exception of Gotts' (2007) overview of synergies with resilience ideas, world systems approaches remain relatively unexplored in the resilience literature.

World systems analysis is generally recognized for providing a useful lens for understanding the nexus between global and local processes and trends. However, among its critiques is a failure to adequately consider the role and dynamics of space, particularly its material and biological characteristics, in structuring and organizing the global political economy and its subsequent impacts on the natural environment (Bunker 2003). As noted by Mauro (2009), more recent strands of WSA have paid greater attention to biophysical features and systems. One particularly noteworthy contribution has been the work of sociologist Stephen Bunker and his collaborators. His materio-spatial perspective (Bunker 2003) explicitly considers the role of material and biogeo-physical dimensions in driving social and ecological change across spatial and temporal scales (Table 1). This particular world systems perspective merges WSA with historical materialism and is referred to as "new historical materialism" in later work (Bunker and Ciccantell 1999, 2005a, $b, c)$.

Materio-spatial world systems analysis, henceforth, materiospatial WSA, is best illustrated in Bunker's (1984, 1985, 2003) inquiries into the exploitation and environmental degradation of the Amazon Basin. He delineates how physical and biological characteristics of specific natural resources, in combination with topographic and hydrological features of the landscape and climatic conditions, have structured (and continue to do so) both local and global dimensions of the world system, which has driven the environmental destruction of the Amazonian rainforest. He shows, for example, how during the rubber boom in the late $1800 \mathrm{~s}$ the biological characteristics of rubber trees, the course and flow of the rivers, and the seasonal patterns of rainfall and flooding "constrained and molded" the local organization of rubber extraction and "limited and destabilized supplies to an industrializing world increasingly dependent on and enriched by rubber's role in production" (Bunker 2003:232-233). This mix of material and social dynamics in the periphery of the world system ultimately set the conditions for powerful actors in core nations to transform what was a wild plant "where British capital 'controlled neither land nor labor"” (Brockway 1979, as cited in Bunker 2003:233) into a highly controlled and environmentally damaging plantation crop in Asia.

At the heart of materio-spatial WSA is the notion of "flows of energy." The main premise is that the demand for raw materials from the core, i.e., nation states and, increasingly, transnational networks of organizations and people, has led to "accelerated flows of energy" from extractive to productive economies (Bunker 1985:33). Global inequities and environmental degradation are seen as the product of this transfer of materials and the values embedded in them. In particular, these continuous flows of energy have enabled the core to develop, or increase its complexity, laying the institutional foundations for wealth accumulation, concentration of power, and technological innovation (Bunker 1985). This "hypercoherence" at the core (Bunker 1985:253) has come at the expense of peripheral regions, which, as their resource bases become more and more depleted, their capacity to become more complex and influential in global patterns of exchange, is constrained. And, herein lies the "fatal contradiction" (Mauro 2009:120) of the modern (capitalist) world system (see also O'Connor 1997). Although these flows of energy are central to sustaining the modern world political economy, they are accelerating global environmental degradation and, thus, are a fundamental threat to the very existence of dominant global political-economic-regulatory-ideological systems. This cursory summary highlights some of the general world system level processes and trends elaborated in WSA and in Bunker and colleagues' materio-spatial perspective. As noted by Prew (2003), among others, the dynamics and consequences of these flows of energy vary within peripheral regions, shaped differentially by historical and other social and biophysical contextual factors.

Materio-spatial WSA is one example of a structuralist social science perspective that combines an understanding of multiscalar and complex social dynamics while also explicitly integrating ecology in analyses. Other examples include Moore's (2011) notion of capitalist world-ecology and structuralistoriented political ecology studies. Although their historically grounded, multiscalar, and systemic lens is valuable for understanding globalization processes and trends, WSA and related structural approaches have come under considerable critique (e.g., Chirot and Hall 1982, Navarro 1982, Giddens 1984, Granovetter 1992, Chase-Dunn and Grimes 1995, Hall 2000). The most pervasive criticism is an implicit structurally deterministic and reductionist view of people, one that assumes that human behavior is driven automatically and unconsciously by social and biophysical structures and processes. Critics argue that such a simplistic view of human and nature interactions limits our understanding of the interconnectedness and nonlinear relationship across social and ecological domains and scales of change. Scholars have suggested ways to address these limitations, including incorporating contextually rich structural fieldwork methods in WSA (Gellert and Shefner 2009) and complimenting WSA with political ecology (Mauro 2009). Others have pointed to world systems scholars' continuous refinement of core notions and expansion into new realms (Chase-Dunn and Lawrence 2010).

\section{CRITICAL REALIST POLITICAL ECOLOGY: A RETURN TO ECOLOGY}

Political ecology and resilience thinking have had a relatively longstanding engagement, gaining prominence with Peterson's (2000) resilience-oriented approach to political ecology and, most recently, Turner's (2013) exploration of the resilience-political ecology alliance. The intellectual nexus between these two fields has generated a lively arena of interdisciplinarity, including empirical studies (Michon 2011, Widgren 2012), debates (Peterson and Hornborg 2012), and an online forum (G. Peterson 
Table 1. An overview of three bodies of social science scholarship that explicitly incorporate ecological dimensions.

\begin{tabular}{|c|c|c|c|}
\hline & \multicolumn{2}{|c|}{ Integrative Approaches } & \multirow{2}{*}{$\begin{array}{l}\text { Hybrid Perspectives } \\
\text { Actor-network theory (ANT) }\end{array}$} \\
\hline & Materio-spatial world systems analysis & $\begin{array}{l}\text { Critical realist political } \\
\text { ecology }\end{array}$ & \\
\hline $\begin{array}{l}\text { Disciplinary } \\
\text { foundations }\end{array}$ & Sociology & Human geography & $\begin{array}{l}\text { Sociology - Science and Technology } \\
\text { Studies }\end{array}$ \\
\hline $\begin{array}{l}\text { Emergence of the } \\
\text { field }\end{array}$ & $1980 \mathrm{~s}$ & $1990 \mathrm{~s}$ & $1980 \mathrm{~s}$ \\
\hline Notable scholars & Stephen Bunker, Paul Ciccantell & Tim Forsyth & Bruno Latour, Michel Callon, John Law \\
\hline $\begin{array}{l}\text { "Where is the } \\
\text { ecology?" }\end{array}$ & $\begin{array}{l}\text { Integrated into the materio-spatial } \\
\text { WSA framework }\end{array}$ & $\begin{array}{l}\text { Biophysical world acknowledged as } \\
\text { "real" but can never be fully objectively } \\
\text { apprehended }\end{array}$ & $\begin{array}{l}\text { Human and nonhuman, including } \\
\text { biophysical, actors incorporated into } \\
\text { analyses }\end{array}$ \\
\hline $\begin{array}{l}\text { Assumptions about } \\
\text { human-environment } \\
\text { relationship }\end{array}$ & $\begin{array}{l}\text { Conceptual separation of humans/ } \\
\text { society and biophysical world }\end{array}$ & $\begin{array}{l}\text { Conceptual separation of humans/ } \\
\text { society and biophysical world }\end{array}$ & $\begin{array}{l}\text { "Social" does not exist; relations among } \\
\text { humans are always mediated by } \\
\text { nonhuman entities, i.e., material, } \\
\text { technological, biophysical }\end{array}$ \\
\hline $\begin{array}{l}\text { Drivers of social- } \\
\text { ecological change }\end{array}$ & $\begin{array}{l}\text { Interconnected multiscalar biophysical } \\
\text { and social structures and processes; } \\
\text { "flows of energy" }\end{array}$ & $\begin{array}{l}\text { Ecological degradation and social } \\
\text { inequities exacerbated by environmental } \\
\text { orthodoxies }\end{array}$ & $\begin{array}{l}\text { Continuous processes of change that } \\
\text { emerge from "acts of translations" in } \\
\text { actor-networks }\end{array}$ \\
\hline \multirow{2}{*}{$\begin{array}{l}\text { Primary units of } \\
\text { analysis and } \\
\text { analytical approach }\end{array}$} & World systems structures and processes & $\begin{array}{l}\text { Knowledge production and } \\
\text { contestation }\end{array}$ & $\begin{array}{l}\text { Actors, humans and nonhumans, and } \\
\text { actor-networks }\end{array}$ \\
\hline & Materialist, structuralist analyses & $\begin{array}{l}\text { Poststructuralist analyses, within a } \\
\text { realist ontology }\end{array}$ & $\begin{array}{l}\text { Material-semiotic approaches that } \\
\text { "follow the actors" and "processes of } \\
\text { networking" }\end{array}$ \\
\hline \multirow[t]{3}{*}{$\begin{array}{l}\text { Strengths for } \\
\text { resilience inquiries }\end{array}$} & $\begin{array}{l}\text { Explicit consideration of biophysical } \\
\text { dimensions in understanding social- } \\
\text { environmental change }\end{array}$ & $\begin{array}{l}\text { Poststructuralist analysis within a } \\
\text { realist ontology }\end{array}$ & $\begin{array}{l}\text { Explicit consideration of both human } \\
\text { and nonhuman entities and their role in } \\
\text { social-ecological phenomena and } \\
\text { change }\end{array}$ \\
\hline & Systems approach & $\begin{array}{l}\text { Incorporation of issues of power and } \\
\text { politics of science }\end{array}$ & $\begin{array}{l}\text { Transcendence of local, regional, and } \\
\text { global, and other dualism }\end{array}$ \\
\hline & Long-term, historical perspective & $\begin{array}{l}\text { Focus on how to improve science for } \\
\text { environmental policy and management }\end{array}$ & $\begin{array}{l}\text { Network and process (networking) } \\
\text { approach }\end{array}$ \\
\hline \multirow[t]{3}{*}{$\begin{array}{l}\text { Limitations and } \\
\text { challenges for } \\
\text { resilience inquiries }\end{array}$} & $\begin{array}{l}\text { Somewhat deterministic and } \\
\text { reductionist view of human behavior }\end{array}$ & $\begin{array}{l}\text { Limited analysis of the role of } \\
\text { biophysical dimensions in driving } \\
\text { change }\end{array}$ & $\begin{array}{l}\text { Jargon-laden language; difficult to } \\
\text { understand and apply }\end{array}$ \\
\hline & & $\begin{array}{l}\text { Focus on local contexts may limit the } \\
\text { identification of generalizable findings }\end{array}$ & $\begin{array}{l}\text { Individual-level characteristics of } \\
\text { people; intangibles; politics/power; and } \\
\text { biophysical dimensions not well } \\
\text { incorporated }\end{array}$ \\
\hline & & & $\begin{array}{l}\text { Imbalances and differences among } \\
\text { actors in a network overlooked }\end{array}$ \\
\hline
\end{tabular}

2012, http://rs.resalliance.org/2012/04/22/political-ecology-andresilience/). The numerous tensions and potential synergies between political ecology and resilience have been covered thoroughly in these various outlets. What remains largely unexplored is a relatively recent strand of political ecology that explicitly engages ecology and biophysical change while incorporating poststructuralist questions of knowledge, framings, and power: critical realist political ecology (Forsyth 2001, 2003). This "ecologically-based political ecology" perspective (Walker 2005:79) is part of, in the words of Turner (2013:4), "only a small fraction of work [...in political ecology] focused on understanding the relationship between social and 
environmental change [compared to poststructuralist analyses of power and knowledge]." Resilience scholars have had limited engagement with this area of political ecology, which offers potential for strengthening the interface between the two areas of scholarship.

Critical realist political ecology emerged from a series of ongoing intellectual tensions, which have marked the field since its establishment in the 1970 s. As noted by numerous authors, political ecology encompasses a broad set of theoretical perspectives and analytical frameworks and approaches (see Greenberg and Park 1994, Turner 1997, Forsyth 2003, 2008, Walker 2005, Muldavin 2008, Rocheleau 2008, Turner and Robbins 2008). Nonetheless, two overarching phases can be distinguished: a structuralist phase, spanning the 1980s and early 1990s, and a poststructuralist phase in the 1990s. The former focused on the role of the political economy, including capitalism and state policies, in land degradation. In contrast, the latter turned attention to "local-level studies of environmental movements, discursive and symbolic politics, and the institutional nexus of power, knowledge and practice" (Walker 2005:75). The earlier structuralist-oriented studies gave the biophysical environment a central role in analyses (Bunker 1985, Hecht 1985, Watts 1985, Blaikie and Brookfield 1987, Turner 1993). They eventually came under criticism for being overly deterministic and "ecology without sufficient politics" (Bassett and Zimmerer 2004, Walker 2005). This paved the way for the emergence of poststructuralist approaches that paid explicit attention to nonmaterial dimensions of power, notably knowledge production (Escobar 1996, 1998, Stott 1999). The field of political ecology shifted considerably. Scholars were discouraged by journals from placing equal emphasis on biological and social dimensions of ecology; and empirical, quantitative, and ecological data became deemed unnecessary and excessive (Rocheleau 2008). This "new focus of 'political ecology' on politics" (Walker 2005:75; emphasis in original) or "politics without ecology" (Vayda and Walters 1999), although acknowledged for broadening the horizon of political ecology, it too eventually came under criticism for insufficiently engaging the biophysical world (Walker 2005). It spurred a return to ecology in political ecology (Walker 2005, Rocheleau 2008). Since the mid-1990s, numerous studies have reincorporated into their analyses the role of biological and material dimensions across a variety of landscapes and environmental issues, but in ways that differ from the earlier structuralist approaches (Rocheleau 2008). Most notable are the critical realist studies of Forsyth (2001, 2003) and Forsyth and Evans (2013).

Critical realist political ecology, henceforth, critical realist PE, is concerned with the complex and contingent interconnections between the biophysical and social realms in explaining environmental change (see Table 1). Critical realist PE acknowledges that there is a "biophysically real world out there" (Forsyth 2003:2) and that environmental problems are real and independent of human understanding, i.e., a realist ontology. However, it posits that this reality is never fully apprehendable, i.e., adopts a critical realist epistemology. Therefore, natural scientific explanations of environmental change and degradation are argued to provide only limited insights into actual complex biophysical processes and, as such, can exacerbate environmental crises and social injustices. This is the reason why critical realist $\mathrm{PE}$ integrates poststructuralist perspectives into its analyses.
This poststructuralist lens highlights the political context of science and the institutional and power dynamics that elevate certain bodies of knowledge, particularly scientific knowledge over others, and the ensuing environmental and social consequences. For example, Forsyth (1996, 2001, 2003) demonstrates, through empirically rich case studies, how primarily equilibrium-based, scientific explanations of environmental change and degradation become decontextualized "environmental orthodoxies," or undisputed truths, leading to narrow framings of problems and solutions and to social injustices. One such environmental orthodoxy was the Himalayan Environmental Degradation theory, which arose in the 1970s and claimed that population growth in Nepal was leading to soil erosion. Subsequent interdisciplinary research in the 1980s revealed a much more complex blend of biophysical and socio-political processes behind the increases in deforestation and landslides (Forsyth 2001). Although critical realist PE emphasizes that it is not possible to "uncover the 'reality' of biophysical environmental processes in any absolute or final way" (Forsyth 2001:8), it does not seek to just deconstruct scientific narratives. Rather, as Forsyth (2001:2) emphasizes, the aim is to "reconstruct new and more effective science for environmental policy that is both biophysically more accurate than existing conceptions, and socially more just." This is what was accomplished, through extensive empirical interdisciplinary research, in the Himalayan soil erosion case.

Critical realist PE is not without challenges or problems. Forsyth (2001), for example, noted that incorporating the values and experiences of local people necessary to build explanations that are more socially relevant means that they may, although not necessarily, have limited applicability outside the locality in which they are developed. This "Achilles heel of localism" (Bryant and Bailey 1997:24) is often incompatible with human-environment approaches that seek to identify generalizable principles, including in resilience research, although some approaches use case studies to generate a ground-up set of general propositions (see Anderies et al. 2006).

Critical realist analyses are not the only strand of political ecology that have sought to bring ecology back in and offer potential for productive cross-fertilization with resilience ideas. Other noteworthy studies include Ogden's (2011) and Ogden et al.'s (2013) work, best illustrated by her analysis of the Everglades in Florida, USA in which she incorporates multiple species, both human (hunters and scientists) and nonhumans (alligators and mangroves) to understand the "politics of other species" and "what constitutes the human" (L. Ogden 2012, http://www. aaanet.org/sections/ae/index.php/laura-ogden-engagement-interview/). Zimmerer's (2011) study of spate irrigation in the Bolivian Andes merges concepts from nonequilibrium ecology, political ecology, and actor-network theory. And studies in urban political ecology have drawn on hybrid perspectives and techniques to illustrate how urban environments and social change codetermine each other (Gareau 2005, Holifield 2009, Zimmer 2010, Heynen 2014).

\section{ACTOR-NETWORK THEORY: HYBRIDS OF SOCIETIES-} NATURES

Actor-network theory, or ANT, offers provocative insights and challenges to the fields of both resilience and the environmental social sciences. Actor-network theory emerged in the 1980s from the realm of Science and Technology Studies. Most frequently 
associated with the sociologists and anthropologists Bruno Latour, Michel Callon, and John Law (Callon and Latour 1981, Callon 1986, 1987, Latour 1993, 1996, 2005, Law 1990, 1992, 1999, Callon and Law 1995), ANT approaches have since rapidly spread across a range of subfields in sociology, geography, management and organization studies, economics, anthropology, and philosophy (Cressman 2009). To date, the application of ANT within resilience studies has been limited. Two notable exceptions are Zimmerer's (2011) case study of spate irrigation in the Bolivian Andes, and Dwiartama and Rosin's (2014) use of ANT approaches to understand the resilience of Indonesian rice and New Zealand kiwifruit crop production systems.

Rather than a unified theory, ANT is argued to be a "disparate family of material-semiotic tools, sensibilities and methods of analysis" (Law 2007:2) meant to sensitize researchers, through empirically rich research practices, to the complexity of socialmaterial/techno-ecological realities and the role of nonhumans in social life (Law and Singleton 2013). From an ANT perspective, the domain of the social, i.e., social relations among humans, does not exist (see Table 1). Rather, ANT begins with the ontological premise that relations among humans are "always mediated and transformed and even enabled by nonhumans of diverse kinds, whether objects, materials, technologies, animals or eco-systems" (Nimmo 2011:109). The adoption of this "flat ontology" or "generalized symmetry," in which nothing or no one is privileged at the start of the analysis, means that a human is treated a priori as having no more agency than a nonhuman entity, e.g., material objects, nonhuman organisms, and physical entities. Likewise, a conventionally understood macroactor, e.g., the state, the global economic system, or climate change, is not assumed to necessarily be more important than a microactor, such as a peasant or a stream.

It thus follows that the main analytical focus of ANT is on hybrids of societies-natures or actor-networks (Latour 1993). Constituted by a heterogeneous mix of human and nonhuman actors, or actants, actor-networks differ from conceptualizations of social networks as social structures and social institutions conventionally used in the social sciences and resilience studies (Latour 1996, Bodin and Crona 2009, Crona and Hubacek 2010, Moore and Westley 2011, Rathwell and Peterson 2012). In ANT, the focus is not on the structure of networks, which according to Latour (1996:2) represent "only one of the possible final and stabilized state of an actor network." Rather, what is important is the process of networking, (i.e., how human and nonhuman actors are brought together, interact, and affect each other) and how, as they interact with each other, actors within the networks are affected, i.e., change how they act or what they do, as well as the network itself (Cressman 2009). As such, ANT approaches focus on mapping "the way in which they [actors] define and distribute roles, and mobilize or invent others to play these roles" (Law and Callon 1988:285). These actor-networks have been used to understand a range of phenomena, including: the operation of scientific laboratories and projects (Latour and Woolgar 1979); the domestication of scallops (Callon 1986); development projects (Gareau 2012, Faik et al. 2013, Heek 2013, Scott-Smith 2013); environmental conservation (Davis and Zanotti 2014); ecosystem services (Ernstson 2013a); sense of community (Sheehan and Vadjunec 2012); public expenditure management information systems (Stanforth 2006); diseases (Mol 2002); economic markets and organizations (Callon et al. 2007, Roberts
2012); and urban planning processes (Ruming 2008, Boelens 2010, Spinks 2011, Rydin 2013).

In actor-networks, change is more or less constant and, thus, understanding the dynamics of change is at the heart of ANT analyses. As Callon notes (1987; emphasis added), an actornetwork is "simultaneously an actor whose activity is networking heterogeneous elements [i.e., humans and nonhumans] and $a$ network that is able to redefine and transform what it is made of." What makes some actor-networks stable or durable and others disappear is a key focus of ANT. Also central to ANT analyses is understanding how new phenomena emerge in the process of networking. Actor-networks are seen as being created and changed via an accumulation of acts of "translations." Among human actors, this is a process whereby one actor seeks to shape the thoughts and behavior of other actors by reinterpreting or displacing their interests or identities to align them with their own (Law 1992). The current struggle between climate change believers and sceptics is an example of human actors within two global actor-networks trying to persuade or translate each other, as well as those who stand on the fence, into their camp.

Methodologically and analytically, understanding these processes of change entails following and mapping the actors and the actornetworks, including ones that emerge and others that disappear "in the making" (Latour 1987). At the heart of this mapping is a material-semiotic approach, which involves tracing relations among things (i.e., material) and concepts (i.e., semiotic). Ethnographies and microlevel analyses of place-based settings have been traditionally used. However, since its emergence in the 1980s, ANT has moved from the classic ANT approach, based on participant observations and rich ethnographies, to post-ANT "sensibilities" (see Mol 1999, Baiocchi et al. 2013, Law and Singleton 2013). In doing so, ANT has extended its toolkit of methodologies to incorporate historical analyses (Law 1990, Nimmo 2011), as well as mixed qualitative-quantitative methods. These include citation analysis (scientometrics) and cooccurrence analysis, digital cartography, and ANT-specific software, such as IssueCrawler (Rogers and Marres 2002), the médialab toolkit (Venturini and Latour 2010), and actor-network text analyzer or ANTA (see discussion by Venturini and Guido 2012).

Although ANT studies tend to start with a focus on a particular location, the process of tracing the connections and relations among humans and nonhumans means that ANT analyses transcend the local, regional, and global. A farmer, for example, is almost always linked to the global market and regional climate patterns, and these connections emerge during the analysis. Without losing its foothold in place-based localities, ANT has been applied to understand processes of globalization. A classic example is Law's (1990) study of fifteenth and sixteenth century Portuguese expansion. Other related studies include Castells' (1996, 1997, 1998) and Urry's (2000, 2005) work on scapes and flows, which draws on complexity science and ANT to analyze contemporary globalization processes (see also Mol 2007). Scapes refer to "the networks of machines, technologies, organizations, texts and actors that constitute various interconnected nodes along which flows can be relayed" (Urry 2000:35). The flows, which move along and are structured by these socio-material networks or scapes, "consist of peoples, images, information, money and waste, that move within and especially across national 
borders and which individual societies are often unable or unwilling to control directly or indirectly"(Urry 2000:36). As with ANT's notion of actor-networks, scapes also can be stabilized and destabilized. Although Castells and Urry's work sits more firmly with complexity theory, the rejection of the dichotomy between the social and the material in their notions of scapes and flows reflects their assimilation of ANT concepts (Mol 2010).

Despite its growing popularity, ANT remains a controversial approach (Alcadipani and Hassard 2010). One significant challenge is ANT's highly abstract and jargon-laden language. As noted by Latour (2005) and Cressman (2009), among many others, ANT is notoriously difficult to summarize, explain, and understand without having actually attempted to apply it. This is far from insignificant but scholars are making strides in translating ANT into more accessible language and for use in applied fields (see Cresswell et al. 2010, Faik et al. 2013, Ryden 2013, Scott-Smith 2013). Actor-network theory has also been criticized for not adequately incorporating individual-level aspects and intangibles such as values, morals, culture, human intentions, and learning (Radder 1992, Miettinen 1999, McLean and Hassard 2004, Gad and Jensen 2010), and for its neglect of politics (Walsham 1997 as cited in Alcadipani and Hassard 2010). Moreover, its treatment of all actors as symmetrical is problematic on several grounds. Not only is there an analytical focus on human actors, but there is also a tendency to not acknowledge the imbalances and differences between actors within a network, such as humans' unique ability to imagine, reflect, and learn (Kirsch and Mitchell 2004, Laurier and Philo 1999 as cited by Castree 2002; G. Watson unpublished report). Some scholars have proposed that these shortcomings can be overcome by complementing ANT with other social theories such as political ecology (Ivakhiv 2002, Robbins 2004, Cherlet 2010). Others have applied ANT to issues of inequity and injustice (Holifield 2009, Ernstson 2013a, b) and incorporated into ANT analyses norms, values, and other intangible dimensions of the social world (Heek 2013).

There are other strands of hybrid scholarship that potentially have much to offer resilience thinking. Some of these are beginning to be explored (see, for example, Berghoefer et al. 2010). Other approaches include critical geographers Whatmore's (2008) and Braun's (2005) notion of more-than-human, as well as Whatmore's (2002) and Hinchliffe's (2007) a-modern, i.e., neither modernist nor postmodern, social science that places emphasis on "the notion that we live in lively, unstable worlds that are always 'a commotion'... always surprising, always in a state of becoming" (Rudy and White 2014:129). There are also intellectual traditions within the social sciences that neither use the term, nor are labelled as, hybrid but that reject dualistic understandings of humans and nature. These include anthropologist Strang's (2005, 2006, $2011 a$, $2011 b$ ) notion of fluidscapes, which emphasize the relational and comingling relationships between physiological characteristics of water, human sensory experiences, and cross-cultural meanings around water, its use, and management.

\section{FOSTERING INTERDISCIPLINARY AND TRANSDISCIPLINARY RESILIENCE: SOME POTENTIAL AVENUES}

Materio-spatial world systems analysis, critical realist political ecology, and ANT perspectives have much to offer resilience ideas, both on a conceptual and on a practical level. These three ecologically integrative and hybrid perspectives can enrich and broaden resilience thinking's conceptualization and analyses of the social in social-ecological systems and dynamics, broadly, and human agency and power, more specifically. The contribution of these perspectives for resilience-in-practice is covered only indirectly because of space limitations.

\section{Unpacking the social and human-environment dynamics and change}

Social-ecological systems and resilience through the lens of world systems and energy flows

World systems analysis and resilience thinking are highly compatible and complimentary. They share, among other things, an analytical focus on systems, structures, and processes; attention to local-global connections, and spatial and temporal dynamics in determining environmental change and degradation; and links to complex systems thinking (Gotts 2007). Similar to resilience inquiries, world systems approaches essentially seek to uncover how "the processes of the system affect the internal dynamics and social structures of its components [and how] changes within its components affect the entire system" (Hall 2000:6). This conceptual compatibility opens the door for closer integration of WSA and resilience approaches.

One value of WSA for resilience inquiries is its emphasis on world systems, or global processes and patterns for understanding intraand multiscale human-environment dynamics and consequences. As one of several conceptual frameworks for understanding globalization, it has the potential to enrich resilience analyses of global environmental change, global governance and stewardship, planetary boundaries, and multiscale resilience, all burgeoning areas of interest and scholarship (Armitage and Johnson 2006, Rockström et al. 2009a, b, Folke and Gunderson 2010, Folke et al. 2010, Gupta and Pahl-Wostl 2013a, $b$, Galaz et al. 2014). World systems analysis' longitudinal lens, in particular, offers the prospect of a more nuanced, historically grounded understanding of the emergence of our globalized world, and its role in accelerating "nested and teleconnected" ecological destruction, social vulnerabilities, and associated losses of resilience (Adger et al. 2009).

Adding Bunker and colleagues' materio-spatial lens further enhances the potential of pairing WSA and resilience thinking through its explicit attention to the biophysical world and the ways in which place-based material and ecological dynamics shape the interconnectedness of the world. In particular, tracing and understanding how flows of energy have affected the socialecological resilience of local places, regions, and the planet merits further exploration. One possible avenue is linking a flows of energy perspective with the adaptive renewal cycle and panarchy heuristic models (Holling 1986, Holling and Gunderson 2002, Gunderson and Holling 2002). This combined analytical perspective offers a historically grounded response to Armitage and Johnson's (2006) call for greater empirical understanding of the "contingent relationship among slow and fast variables in the context of globalization." A materio-spatial WSA perspective draws attention to the role of movements of raw materials, from peripheral regions to core nations and transnational webs of actors, in building and sustaining the contemporary global political economy and its social and environmental consequences, i.e., the front loop or exploitation and conservation phases. It also provides insights into the prospects for a transition to a more 
sustainable global regime. In their work, Bunker and Ciccantell $(1999,2005 a, b, c)$ highlight the interplay between unprecedented levels of "hypercoherence" (connectedness in adaptive renewal cycle terminology) among nation states, firms, and financial institutions; accelerated flows of energy; and escalating ecological degradation and poor labor conditions. Integrating these into the adaptive renewal framework provides an additional world systems level understanding of material and social conditions that have the potential to trigger a backloop, or creative destruction and reorganization of the global political economy. Bunker and Ciccantell (2005a) identify international strategic alliances that challenge current free-trade agreements and global networks between civil society and states in both consumer countries and extractive economies as potential mechanisms for triggering transformation and radical change (i.e., revolt in panarchy language).

\section{Social-ecological systems as fluid actor networks and resilience- in-the-making}

Actor-network theory offers a very different understanding of our world; one in which humans and nonhumans are intricately intertwined in hybrid networks of actors that are in constant flux. This resonates with resilience thinking's view of SESs as intrinsically coupled, dynamic, and nonlinear (Folke et al. 2004, Trosper 2005). However, ANT takes the metaphor of "coupled" a step further by proposing that there is no such thing as social phenomena or, for that matter, social subsystems. This presents resilience thinking with some interesting challenges as well as opportunities. Resilience inquiries typically use the conceptual lens of social-ecological systems, ecological and social subsystems, and notions of controlling variables, slow and fast variables, and exogenous and internal factors, among others, to explain resilience. In contrast, ANT begins with the premise that "there is no overall social, natural or conceptual framework or scale within which events take place: as webs grow they tend to grow their own metrics" (Law 2007:8).

An ANT-informed approach to resilience essentially proposes a different starting point for understanding and assessing socialecological resilience, one that goes "through the back door of [resilience] in the making" (Latour 1987:4; emphasis added). In the words of Law (1992:380), this entails "start[ing] with a clean state," that is, putting to the side, at least initially, commonly employed analytical concepts, frameworks, and heuristic models used in resilience research. Otherwise, our capacity to capture the complexity and "fluidity of reality" (Cresswell 2009:3, Law 2007) is constrained and there is the "risk...[of] closing off most of the interesting questions about the origin of [resilience]" (Law 1992:380; emphasis added). This does not imply that an ANT approach to resilience negates the existence of slow and fast variables, or external drivers and internal pressures, for example. Rather, it advocates holding off making assumptions, a priori, about what actors, or, in resilience language, what variables, structures, and subsystems, etc., of an SES constitute controlling variables, external drivers, and so forth. That is because, according to ANT, the identities, roles, and agency of the actors are never static, predictable, or controllable; they change as actors interact with each other and the actor network(s) in which they are embedded.
As such, an ANT approach to resilience would entail "follow[ing] the actors [and actor-networks] themselves" (Latour 2005:12), using a material-semiotic approach. This involves mapping all the known actors, which can be captured using conventional social network analysis tools (e.g., Rydin 2013). The focus of the analysis would be on tracing how relations or associations among human and nonhuman actors are negotiated, play out, and take shape, i.e., the moments of translation (Callon 1986). From an ANT perspective, this is argued to be essential for revealing what particular configurations of, and associations among, actors turn out to act as slow variables, for example, and whether a particular actor network, or SES in resilience terminology, is resilient or at a tipping point in a particular place, scale, and point in time. Detailed mappings of the heterogeneous actors and how their relationships are formed, negotiated, (temporarily) maintained, and reshaped can provide empirically rich understandings of how particular associations lead to comanagement arrangements; strong cross-scale networks; increased capacity for learning, adapting, and transforming; and other features that have been highlighted in the literature and practical experiences as important sources of resilience. Likewise, this material-semiotic approach can be used to better understand what types of socialmaterio/techno-ecological associations undermine socialecological resilience.

Actor-network theory thus essentially proposes a microperspective and descriptive approach to resilience, one that is founded on empirically grounded studies that tell stories about how relations assemble and uses these to build up explanations of resilience (Law 2007). This lens into the microcosm, so to speak, of resilience is capable of capturing multiscalar, including local-global, dynamics as the analysis is not a priori confined to any particular scale. Such an analysis can be complemented with Castells and Urry's $(2000,2005)$ notions of scapes and flows, which explicitly incorporate the global scale. Scapes and flows can be used to investigate how particular combinations and intersections of people, materials, ideas, and ecologies dispersed in specific timespace patterns give rise to different resiliencescapes (see the notion of tourismscapes by van der Duim 2005, 2007).

Additionally, as with materio-spatial WSA, there are potential synergies with resilience thinking's adaptive renewal cycle and concept of panarchy. A key aspect of ANT studies is exploring how actor networks are assembled, ordered, and reconfigured over time (Law 1992). A material-semiotic approach to analyzing the dynamics of change highlighted in the adaptive renewal cycle and panarchy model has the potential to add some complementary, as well as unique, insights to the body of work around these resilience-related frameworks. For instance, ANT's conceptualization of actor-network formation as comprising four moments of translation (Callon 1986) can be extended to analyzing periods of exploitation, or the $r$ phase, in SESs. Similarly, ANT notions of material and strategic durability, discursive stability, ordering, normalization, punctualization, and black boxes, all of which are used to describe periods of moreor-less stability in actor networks, have the potential to offer a material-semiotic understanding of periods of growing stasis and rigidity, i.e., the conservation or $\mathrm{K}$ phase. Periods of readjustments and collapse, the release or $\Omega$ phase, and reorganization and renewal, the $\alpha$ phase, can also be viewed through ANT notions of dissidence and discontinuities. 
In sum, an ANT approach to understanding SESs and analyzing resilience does not necessarily invalidate or replace other humanenvironment approaches, including the frameworks and heuristics conventionally used in resilience inquiries. For a comparable and more nuanced discussion of the synergies and tensions between ANT and other ontologically different approaches, see Holifield's (2009) overview of Marxist political ecology and ANT. However, it enables resilience scholars to do something different: to look at SESs, and their resilience, as fluid. This is aligned with the resilience-thinking's view of complex systems as dynamic, characterized by nonlinear feedbacks, and unpredictable. Importantly, ANT's "following the actors" approach highlights that although you may have similar actors in different SESs, such as, adequate rainfall and strong community leadership, their presence alone may not necessarily lead to resilient outcomes. Rather, it is the broader constellation of actors of which they are a part, and processes of translation and associations among these actors, that are key to understanding how and in what form resilience emerges in a particular place, time, and scale. Such contextually based analyses, carried out across a range of places and situations, have the potential to reveal common patterns or generalizable principles for resilience.

\section{Broadening the lens on (human) agency}

A recurrent concern with resilience thinking has been its relative inattention to human agency, at both the individual and collective levels (Davidson 2010, Brown and Westaway 2011, Cote and Nightingale 2012). Davidson (2010:1142) argues that human agency is one of the characteristics that distinguishes social systems from their ecological counterparts and, as such, is an essential "additional conceptual layer" for enhancing our understanding of the conditions needed for resilience. Here, ANT again offers an interesting perspective.

The ANT lens on human agency differs from other social science approaches, such as structure-agency theories (Sewell 1992, Archer 2000), in that it does not a priori focus on the agency of humans. Agency is not seen as an essential characteristic of people. Rather, agency is understood as the capacity to cause an effect, i.e., to make a difference to a state of affairs (Callon 1987, Latour 2005). From this perspective, a farmer, a coastal community, global markets, social norms about conservation, a plant virus, frost events, and crops are all assumed to have the potential for agency. Ernstson (2013b), for example, in his ANTbased exploration of agency in a Cape Town grassroots ecological rehabilitation project demonstrates the role plants had in giving voice to memories of oppression and to the eventual emergence of an environmental movement. In addition, ANT assumes that the agency of human beings, including through their capacity to be reflective, creative, imaginative, and proactive, is tied to the agency of all the actors and the networks themselves, i.e., it is part of a distributed agency (Garud and Karnøe 2003, Rammert 2008). This understanding of a networked agency moves away from the notion of social structures, technologies, and environmental factors as external forces that have an impact upon humans' ability to act, and vice versa.

Actor-network theory thus offers resilience inquiries an approach to human agency within a broader conceptualization of agency. Its material-semiotic methodology provides resilience with a technique to identify the range of possible actors in an SES of interest and to trace their intertwined roles in shaping the world. The value of this generalized-symmetry view of agency for resilience inquiries is that it encourages the explicit consideration of a wide range of humans and nonhumans at the start of an analysis or assessment of resilience. This includes people and their creations, both material (e.g., water pumps, urban planning documents, and spatial arrangement of infrastructure) and intangibles (e.g., ideas about conservation; understandings about inequality, scale, and space; memories of floods; storylines about the origin of landscapes and seascapes; norms governing access to resources; and lessons learnt based on past mistakes). It also encompasses nonhuman organisms (e.g., plants and animals), physical entities (e.g., rocks), and biophysical dynamics and features (e.g., water flows, topographic and hydrological features of the landscape). To date, ANT studies have only superficially incorporated environmental actors. Here, resilience studies can bring to an ANT-informed analysis a more comprehensive and nuanced understanding of the role of biophysical actors, including specific components and dynamics underpinning ecosystems, in shaping humans and social life. Finally, ANT's distributed-agency perspective highlights that the status of the actors in an SES, i.e., whether they are human or not human, is not as relevant as the ways in which they interact with, are mediated by, and have an impact on their relations with each other as well as the actor networks of which they are a part.

Actor-network theory's conceptualization of agency also offers insights into different types or levels of agency. At a broad level, ANT views agency as the capacity to build networks to achieve certain ends. There is also "resistive agency: the capacity to act back, granting or refusing translation" (Fox 2000:863). Actornetwork theory further refines its notion of agency by distinguishing between intermediaries, mediators, boundary objects, and immutable mobiles (Latour 1986, 2005; see also Sayes 2014). For resilience studies, mediators are of particular interest because they are the actors that play a key role in change dynamics by "transform[ing], translat[ing], distort[ing], and modify[ing] the meaning of the elements they are supposed to carry" (Latour 2005:39). Moreover, "no matter how apparently simple a mediator may look, it may become complex; it may lead in multiple directions which will modify all the contradictory accounts attributed to its role" (Latour 2005:39; emphasis added). In other words, mediators can be unpredictable and may disrupt and alter the course of events, resulting in surprises. The concept of mediators thus offers a potentially interesting interpretation of resilience thinking's notions of shocks, drivers, and fast and slow variables and their role in social-ecological change and regime shifts. Actor-network theory's notion of mediator adds value because it moves conceptually beyond discrete entities, such as a particular water management authority or soil organic matter. A mediator can comprise a constellation of actors, i.e., a particular combination of ecological and social structures, processes, and variables, to use resilience terminology. This notion of mediatorsas-networks has the potential to add new insights into the conditions that underpin critical feedbacks and lead to tipping points, thresholds, and regime shifts, including innovation and new more desirable trajectories. The ANT concept of intermediaries is no less important analytically for resilience thinking. They are similar to state variables; they contribute to the formation of stable networks in which the potential for 
significant change is dramatically reduced (Latour 2005). Importantly, however, ANT stresses that the same actor, say a species of bird or a natural resource management planning document, or a certain combination of social, material, and ecological actors, can be an intermediary in one network (or SES), time, or space, and a mediator in another (or a boundary object or immutable mobile, which are not discussed here). Space limits me from delving into these different forms of agency in more detail but what they raise for resilience thinking is the possibility of a more nuanced exploration of who/what are the actors in the SES that is of interest, what kind of agency they enact through their interactions with others and the SES as a whole, and what combinations, i.e., types of actors and types of agency, are important for building resilience.

Actor-network theory's particular perspective on coupled human/ nonhuman agency does not invalidate other analytical approaches, notably constructivist traditions, which have strong legacies in looking at the role of human agency in shaping societyenvironment relationships. These have much to offer resilience thinking (e.g., Miller and Davidson-Hunt 2013). The ANT notion of distributed agency opens a distinctive analytical lens through which to understand how people and nonhumans can influence social-ecological resilience, one that I would argue is not necessarily incompatible with constructivist perspectives on human agency.

\section{Different perspectives on power}

The issue of power has been underscrutinized in resilience thinking (Lélé 1998, Nadasky 2007, Hornborg 2009, Evans 2011) but has recently emerged as an active field of debate and scholarship (Smith and Stirling 2010, Ahlborg and Nightingale 2012, Porter and Davoudi 2012, Phelan et al. 2013, Ratner et al 2013, Fabinyi et al. 2014). Materio-spatial WSA, critical realist $\mathrm{PE}$, and ANT each offer additional contributions to these discussions.

\section{The world systems order and structural sources of power}

World systems analysis puts emphasis on structural sources of power within the world system order. In particular, it highlights the ways in which core nation states, and multiscalar global networks of powerful actors, seek to dominate the world's resources by gaining control over global flows of material and the energy and economic value embedded in them. Bunker and Ciccantell (1999, 2005a, b, c) also consider how geographically explicit hydrological, topographic, climatic, and other bio-geophysical characteristics and processes have an impact upon and determine how these global power structures and relations are exerted, and vice versa. A materio-spatial WSA lens into power thus offers resilience inquiries a historically grounded understanding of how an inherently inequitable global world system has come to structure almost all ecosystems and societies across the planet. It points to the contemporary world (capitalist) political economy and underpinning (neoliberal and modernist) ideological systems as key drivers of social and environmental change globally and in place-based localities. It thus has the potential to add value to resilience studies of globalization, such as Young et al. (2006). Materio-spatial WSA underscores how the social-ecological resilience of peripheral regions is intricately tied to, and undermined by, the resilience of powerful and wealthy core nations and transnational networks. The work of Bunker,
Ciccantell, and other world systems scholars (Prew 2003, ChaseDunn and Lawrence 2010) provide more in-depth analyses of these power dynamics and their social and ecological origins and consequences. Among the nuances offered in their work is the recognition that the core, periphery, and semi-periphery are not static entities. As such, the shape and location of the main productive and extractive nodes of the world economy are not fixed. This means that there are no regions, ecosystems, or people exempt from potentially being impacted by ecological degradation and social disparities.

Complementing resilience inquiries with a materio-spatial lens also raises questions about the potential for alternative, more sustainable global regimes, and what may be the most effective processes of revolt and scales of intervention. By highlighting how pervasive and entrenched, or resilient, the contemporary global political economy is, WSA underscores the structural impediments to changing the current material flows of the global economy. Nonetheless, it also highlights structural interventions that have the potential to reorganize the global world system for greater social justice and environmental sustainability. These include multiscalar global networks and strategic alliances (Bunker and Ciccantell 2005a), and transnational social movements combined with coordinated global governance (Chase-Dunn 2013).

\section{Knowledge systems, science, and power}

Critical realist PE offers resilience thinking a more critical orientation to power relations and dynamics in driving social and environmental change. The value of critical realist PE for resilience is its explicit attention to knowledge systems, in particular science. Complimenting resilience thinking with a critical realist PE perspective thus can contribute to current strands of resilience research around the role, importance, and implications of different bodies of knowledge, including local and indigenous knowledge, in building resilience in SESs (Folke 2004, Reyes-García et al. 2014). However, it also pushes the boundaries of resilience-political ecology engagement by bringing in a critical lens on the production, application, and institutionalization of dominant scientific explanations of the biophysical world. Specifically, it highlights the politics of science, power discrepancies between scientific and nonscientific explanations of environmental change, and how diverse actors at multiple scales use, interpret, question, appropriate, and rework these narratives to meet or serve their own interests and needs. This is very much in line with the broader field of political ecology and its normative commitment to social and environmental justice (Robbins 2004, Turner 2013). A critical realist PE perspective thus invites those engaged with resilience ideas to take a more critical, reflective analysis of their role and that of resilience science as a whole in the debates on, and proposed solutions for, environmental problems and social injustices.

Incorporating a critical realist PE perspective does not dismiss the role that social-ecological resilience, and nonequilibrium ecology more broadly, have had in improving both understanding and management of ecosystems (Zimmerer 2000, Forsyth 2003). However, it highlights that "the adoption of environmental science without acknowledging how it is affected by social and political factors undermines its ability to address the underlying biophysical causes of perceived environmental problems" 
(Forsyth 2003:2). Complementing resilience thinking with this critical lens thus opens up important but challenging questions, including: How have resilience-oriented understandings of SESs been influenced by, and employed within, different power struggles and political debates? Why are the concepts of nonequilibrium ecology and resilience starting to be featured so strongly in many academic and policy circles? Who/what stands to win, and who/what risks losing, as a result of an uncritical adoption of these concepts in environmental policies and management practices? Are the adaptive renewal cycle and panarchy heuristics, for example, sensitive and flexible enough to capture real-world social and ecological diversity and dynamics? Are they capable of informing both ecologically appropriate and socially just and relevant environmental policies, governance arrangements, and management practices? In essence, critical realist $\mathrm{PE}$ challenges resilience approaches to unpack the normative questions of resilience of what and to what (Carpenter et al. 2001), for whom (Lebel et al. 2006), and at what cost to which others (Cote and Nightingale 2012)? It brings to the fore questions around political power, justice, and fairness (Hayward 2013) and highlights that "some people gain while others lose in the process of resilience-building [and that] resilience for some people or places may lead to the loss of resilience of others" (Davoudi et al. 2012:306).

\section{The emergence of power and black boxes}

Actor-network theory looks at power from a different angle: how it emerges as a result of processes of networking among human and nonhuman actors. Rather than looking at capitalist structures and knowledge systems as ways to explain power, social injustices and inequities, and environmental degradation, ANT investigates how these structures and systems "come into being" (Latour 1986, 2005, Holifield 2009, Law and Singleton 2013). Law (1997) argues that studying a specific institution, individual, or a technological apparatus as part of a network reveals that it/he/she is actually relatively powerless. For example, mining companies are not powerful in-and-of themselves; they become powerful by virtue of being "associated with" particular geological materials present in the region, technologies that enable these to be extracted, and national and state regulations that permit mining. However, ANT cautions against presuming, at the onset of an analysis, that conventionally viewed macroactors, such as mining companies, are necessarily bigger or more powerful than microactors (Callon and Latour 1981).

By being empirically based and grounded in a particular context, ANT's "following the actors" approach can provide a situated resilience approach (Cote and Nightingale 2012) to understanding power. Such an analysis provides a unique focus on the moments of translations wherein human and nonhuman actors contest and negotiate resilience of what? to what? for whom? and to what end? In other words, what states and thresholds are desirable, for whom, who gets to decide, and who/ what loses? It gives explicit consideration to the role of nonhumans, such as technologies and topography, in influencing the answers to these questions. This puts the analytical spotlight on the role of tools used in participatory resilience assessments, such as the Resilience Alliance workbook (Resilience Alliance 2011; see also Holifield's (2009) case study of the EPA risk assessment handbooks in the U.S. and Rydin's (2012) urban planning policy documents in the UK). It raises questions about how the Resilience Alliance workbook associates, or ties together, the various actors in an SES and the consequences of this for both people and the ecosystem they inhabit/use. The main value of such an analysis is not a critique of the workbook or broader participatory processes of which it is a part but, rather, bringing to light the ways in which the workbook can unintentionally create winners and losers. Such an understanding opens the door to "experiment[ing] with possibilities for reassembling [the Resilience Alliance workbook and the other human and nonhuman actors involved in a resilience assessment] in better, more just ways" (Holifield 2009:655). As emphasized by Law and Singleton (2013:500), ANT's "explor[ation of] the contingencies of power $[\ldots]$ generates tools for undoing the inevitability of that power."

From an ANT perspective, this analysis is effectively about keeping resilience assessment practices from being "black boxed." In ANT, black boxes consist of "knowledge which is accepted and used on a regular basis as a matter of fact" (Yonay 1994:41). Taken as fact, such bodies of knowledge are no longer scrutinized and thus can become hegemonic and "capable of defining and structuring unequal and potentially unjust configurations of society and nature" (Holifield 2009:647). An ANT-informed analysis of resilience science, and associated practical tools, thus provides a critical lens on potential processes of black boxing. One can argue this is particular timely and valuable given the mainstreaming and institutionalization of resilience thinking and practices in scientific, government, and civil society organizations.

\section{CONCLUDING THOUGHTS}

Social-ecological resilience ideas have moved a long way from their ecological origins and a look at both the scientific scholarship and practical applications reveals a rich engagement with social science concepts, methodologies, and practices. At the same time, in the social sciences and related interdisciplinary fields, there exists a rich diversity of perspectives on how to bring together the social and ecological, some areas of which remain relatively unexplored in the resilience literature. My intention was to highlight a subset of this scholarship and explore the ways in which it can inform as well as broaden resilience perspectives on human-environment interactions and change. Although underpinned by different philosophies of science, materio-spatial world systems analysis, critical realist political ecology, and actornetwork theory all stress the complex, dynamic, and multiscalar characteristics of human-environment relations and dynamics. This provides an avenue for greater engagement with socialecological resilience thinking.

Specifically, materio-spatial WSA, with its materialist- and structuralist-oriented and systems-based analytical lens, is highly complementary to resilience thinking. Because of this conceptual synergy, it offers resilience inquiries an opportunity to explore in greater depth and detail the role of multiscalar political, economic, social, and bio-geo-physical forces in influencing natural-resource use and local people's livelihoods and in shaping social-environmental change across scales and over time. As such, materio-spatial WSA has the potential to contribute to the burgeoning resilience literature focused on understanding socialenvironmental dynamics within the context of globalization (Armitage and Johnson 2006, Young et al. 2006, Galaz et al. 2014). 
Critical realist strands of political ecology offer avenues for exploring and broadening the debate on power and normative issues underpinning resilience thinking and practice. Critical realist PE's marrying of realist and poststructuralist elements, which distinguishes it from "politics without ecology" strands (Vayda and Walters 1999), provides resilience approaches with an ontological and epistemological bridge to engage with poststructuralist analyses of discourses, framings, and power (Carolan 2005). As such, a critical realist PE perspective can enrich existing resilience inquiries into local, traditional, and indigenous knowledge. It also challenges resilience scholars to take a more critical look at how resilience thinking's understandings of social-biophysical systems and dynamics, and core concepts and heuristics, have the potential to both enhance and undermine ecosystem services and human well-being. This is not an easy area of inquiry but the two fields' history of interdisciplinary engagement paves a solid base from which to explore such challenging questions.

The resilience-in-the-making approach offered by ANT entails a "conceptual 'stretching" of resilience thinking (see related discussion by Shaw 2012:310). Some resilience scholars may be uncomfortable with this; others may find it worth exploring. At the end of the day, the compatibility and implications of ANT's actor-network perspective for resilience inquiries depends on what factions and aspects of ANT are used. As noted by Heek (2013) in his exploration of the value of ANT for development studies, ANT can be applied lightly as a methodology for rich descriptions of processes. From this position, ANT can provide resilience inquiries a set of tools for capturing and making sense of the dynamic webs of relations among people and nonhumans in influencing resilience. A stricter application of ANT, on the other hand, proposes an alternative view of the world and how we can best understand it (Heek 2013). From this conservative ANT perspective, resilience thinking's foundational theoretical and analytical concepts, although not invalid, are "of little initial analytical importance" (Law 2007:8; emphasis added). This may be contentious but it does offer an opportunity to bypass the analytically challenging issue of having a priori "to decide what is in and outside the (social-ecological) system" (Walker et al. 2012). It also opens the door for more transdisciplinary avenues of inquiry in resilience research.

In sum, materio-spatial world systems analysis, critical realist political ecology, ANT and social-ecological resilience thinking propose different lenses into human-environment relations and dynamics. As noted by Turner (2008:10), among others, although different approaches to human-environment interactions may not always be reconcilable, "it is possible to appreciate general lessons drawn from one for the other." This was my primary intent: to highlight some points of synergy, as well as constructive tensions, in the hope of illuminating pathways for stronger social scienceresilience engagement, novel inter- and transdisciplinary research, and more effective practices. As Carpenter and Brock (2008) remind us, "resilience is a broad, multifaceted, and loosely organized cluster of concepts...it is a changing constellation of ideas, some of which are testable through the usual practices of natural or social science. Although particular ideas may be rejected or supported, the program of research on resilience itself is evaluated in a different way. As long as resilience thinking produces interesting research ideas, people are likely to pursue it. When it seems empty of ideas, it will be abandoned or transformed into something else."

Responses to this article can be read online at: http://www.ecologyandsociety.org/issues/responses. $\mathrm{php} / 7347$

\section{Acknowledgments:}

The writing of this paper was made possible with the support of a CSIRO Office of the Executive Payne-Scott Award and CSIRO'S Building Resilient Australian Biodiversity Assets (BRABA) theme. Thanks to Erin Bohensky and Toni Darbas for their valuable feedback on earlier versions of this manuscript. I am also grateful for the insightful comments of two anonymous reviewers and Ecology and Society editors.

\section{LITERATURE CITED}

Adger, W. N., H. Eakin, and A. Winkels. 2009. Nested and teleconnected vulnerabilities to environmental change. Frontiers in Ecology and the Environment 7:150-157. http://dx.doi. org/10.1890/070148

Adger, W. N., T. P. Hughes, C. Folke, S. R. Carpenter, and J. Rockström. 2005. Social-ecological resilience to coastal disasters. Science 309:1036-1039. http://dx.doi.org/10.1126/science.1112122

Ahlborg, H., and A. J. Nightingale. 2012. Mismatch between scales of knowledge in Nepalese forestry: epistemology, power, and policy implications. Ecology and Society 17(4): 16. http://dx. doi.org/10.5751/ES-05171-170416

Alcadipani, R., and J. Hassard. 2010. Actor-network theory, organizations and critique: towards a politics of organizing. Organization 17:419-435. http://dx.doi.org/10.1177/1350508410364441

Anderies, J. M., M. A. Janssen, and E. Ostrom. 2004. A framework to analyze the robustness of social-ecological systems from an institutional perspective. Ecology and Society 9(1): 18. [online] URL: http://www.ecologyandsociety.org/vol9/iss1/art18/

Anderies, J. M., B. H. Walker, and A. P. Kinzig. 2006. Fifteen weddings and a funeral: case studies and resilience-based management. Ecology and Society 11(1): 21. [online] URL: http:// www.ecologyandsociety.org/vol11/iss1/art21/

Archer, M. S. 2000. Being human: the problem of agency. Cambridge University Press, Cambridge, UK. http://dx.doi. org/10.1017/CBO9780511488733

Armitage, D., and D. Johnson. 2006. Can resilience be reconciled with globalization and the increasingly complex conditions of resource degradation in Asian coastal regions? Ecology and Society 11(1): 2. [online] URL: http://www.ecologyandsociety. org/vol11/iss1/art2/

Armitage, D., C. Béné, A. T. Charles, D. Johnson, and E. H. Allison. 2012. The interplay of well-being and resilience in applying a social-ecological perspective. Ecology and Society 17 (4): 15. http://dx.doi.org/10.5751/ES-04940-170415 
Baiocchi, G., D. Graizbord, and M. Rodríguez-Muñiz. 2013. Actor-network theory and the ethnographic imagination: an exercise in translation. Qualitative Sociology 36:323-341. http:// dx.doi.org/10.1007/s11133-013-9261-9

Baird, J., R. Plummer, and K. Pickering. 2014. Priming the governance system for climate change adaptation: the application of a social-ecological inventory to engage actors in Niagara, Canada. Ecology and Society 19(1): 3. http://dx.doi.org/10.5751/ ES-06152-190103

Barry, A., and G. Born. 2013. Interdisciplinarity: reconfigurations of the social and natural sciences. Pages 1-56 in A. Barry and G. Born, editors. Interdisciplinarity: reconfigurations of the social and natural sciences. Routledge, New York, New York, USA.

Bassett, T. J., and K. S. Zimmerer. 2004. Cultural ecology. Pages 97-112 in G. L. Gaile and C. J. Willmott, editors. Geography in America at the dawn of the twenty-first century. Oxford University Press, Oxford, UK.

Belsky, J. M. 2002. Beyond the natural resource and environmental sociology divide: insights from a transdisciplinary perspective. Society and Natural Resources 15:269-280. http://dx. doi.org/10.1080/089419202753445106

Berghoefer, U., R. Rozzi, and K. Jax. 2010. Many eyes on nature: diverse perspectives in the Cape Horn Biosphere Reserve and their relevance for conservation. Ecology and Society 15(1): 18. [online] URL: http://www.ecologyandsociety.org/vol15/iss1/art18/

Berkes, F., G. P. Kofinas, and F. S. Chapin, III. 2009. Conservation, community, and livelihoods: sustaining, renewing, and adapting cultural connections to the land. Pages 129-147 in C. Folke, G. P. Kofinas, and F. S. Chapin, III, editors. Principles of ecosystem stewardship. Springer, New York, New York, USA. http://dx.doi.org/10.1007/978-0-387-73033-2_6

Biggs, R., F. R. Westley, and S. R. Carpenter. 2010. Navigating the back loop: fostering social innovation and transformation in ecosystem management. Ecology and Society 15(2): 9. [online] URL: http://www.ecologyandsociety.org/vol15/iss2/art9/

Blaikie, P., and H. Brookfield. 1987. Land degradation and society. Methuen, London, UK.

Blaikie, P., T. Cannon, I. Davis, and B. Wisner. 1994. At risk: natural hazards, people's vulnerability, and disasters. Routledge, New York, New York, USA.

Bodin, Ö., and B. I. Crona. 2009. The role of social networks in natural resource governance: what relational patterns make a difference? Global Environmental Change 19:366-374. http://dx. doi.org/10.1016/j.gloenvcha.2009.05.002

Boelens, L. 2010. Theorizing practice and practising theory: outlines for an actor-relational-approach in planning. Planning Theory 9:28-62. http://dx.doi.org/10.1177/1473095209346499

Bohensky, E. L., J. R. A. Butler, and J. Davies. 2013. Integrating indigenous ecological knowledge and science in natural resource management: perspectives from Australia. Ecology and Society 18(3): 20. http://dx.doi.org/10.5751/ES-05846-180320

Braun, B. 2005. Environmental issues: writing a more-thanhuman urban geography. Progress in Human Geography 29:635-650. http://dx.doi.org/10.1191/0309132505ph574pr
Braun, B., and N. Castree, editors. 1998. Remaking reality: nature at the Millenium. Routledge, New York, New York, USA.

Brown, K. 2014. Global environmental change I: a social turn for resilience? Progress in Human Geography 38:107-117. http://dx. doi.org/10.1177/0309132513498837

Brown, K., and E. Westaway. 2011. Agency, capacity, and resilience to environmental change: lessons from human development, well-being, and disasters. Annual Review of Environment and Resources 36:321-342. http://dx.doi.org/10.1146/ annurev-environ-052610-092905

Bryant, R. L., and S. Bailey. 1997. Third world political ecology. Routledge, New York, New York, USA.

Bunker, S. G. 1984. Modes of extraction, unequal exchange, and the progressive underdevelopment of an extreme periphery: the Brazilian Amazon, 1600-1980. American Journal of Sociology 89:1017-1064. http://dx.doi.org/10.1086/227983

Bunker, S. G. 1985. Underdeveloping the Amazon: extraction, unequal exchange, and the failure of the modern state. University of Chicago Press, Chicago, Illinois, USA.

Bunker, S. G. 2003. Matter, space, energy, and political economy: the Amazon in the world-system. Journal of world systems Research IX:219-258. [online] URL: http://citeseerx.ist.psu.edu/ viewdoc/download?doi=10.1.1.116.5009\&rep=rep1\&type $=$ pdf

Bunker, S. G., and P. Ciccantell. 1999. Economic ascent and the global environment: world systems theory and the new historical materialism. Pages 107-122 in W. L. Goldfrank, D. Goodman, and A. Szasz, editors. Ecology and the world-system. Greenwood, Westport, Connecticut, USA.

Bunker, S. G., and P. S. Ciccantell. 2005a. Globalization and the race for resources. Johns Hopkins Press, Baltimore, Maryland, USA.

Bunker, S. G., and P. Ciccantell. 2005b. From Amsterdam to Amazonia: how space and technology matter in the formation of the capitalist state. Pages 23-44 in P. S. Ciccantell, D. A. Smith, and G. Seidman, editors. Nature, raw materials, and political economy. JAI/Elsevier, Oxford, UK.

Bunker, S. G., and P. Ciccantell. 2005c. Matter, space and technology in past and future hegemonies. Pages in C. ChaseDunn and E. N. Anderson, editors. The historical evolution of world systems. Palgrave, New York, New York, USA.

Burton, I., R. W. Kates, and G. F. White. 1978. The environment as hazard. Oxford University Press, Oxford, UK.

Buttel, F. H. 2002. Environmental sociology and the sociology of natural resources: institutional histories and intellectual legacies. Society and Natural Resources 15:205-211. http://dx.doi. org/10.1080/089419202753445043

Callon, M. 1986. Some elements of a sociology of translation: domestication of the scallops and fishermen of St. Brieuc Bay. Pages 196-233 in J. Law, editor. Power, action and belief: a new sociology of knowledge. Routledge, New York, New York, USA.

Callon, M. 1987. Society in the making: the study of technology as a tool for sociological analysis. Pages 83-103 in W. E. Bijker, T. 
P. Hughes, and T. Pinch, editors. The social construction of technological systems. MIT Press, Cambridge, Massachusetts, USA.

Callon, M., and B. Latour. 1981. Unscrewing the big Leviathan: how actors macro-structure reality and how sociologists help them to do so. Pages 277-303 in K. Knorr-Cetina and A. V. Cicouvel, editors. Advances in social theory and methodology: towards an integration of micro and macro-sociology. Routledge, New York, New York, USA.

Callon, M., and J. Law. 1995. Agency and the hybrid collectif. South Atlantic Quarterly 94:481-507.

Callon, M., Y. Millo, and F. Muniesa. 2007. Market devices. Blackwell, Malden, Massachusetts, USA.

Carolan, M. S. 2005. Realism without reductionism: toward an ecologically embedded sociology. Human Ecology Review 12:1-20. [online] URL: http://www.humanecologyreview.org/pastissues/ her121/carolan.pdf

Carpenter, S. R., and W. A. Brock. 2008. Adaptive capacity and traps. Ecology and Society 13(2): 40. http://www.ecologyandsociety. org/vol13/iss2/art40/

Carpenter, S., B. Walker, J. M. Anderies, and N. Abel. 2001. From metaphor to measurement: resilience of what to what? Ecosystems 4:765-781. http://dx.doi.org/10.1007/s10021-001-0045-9

Castells, M. 1996. The rise of the network society. Blackwell, Malden, Massachusetts, USA.

Castells, M. 1997. The power of identity. Blackwell, Malden, Massachusetts, USA.

Castells, M. 1998. End of Millennium. Blackwell, Malden, Massachusetts, USA.

Castree, N. 2002. False antitheses? Marxism, nature and actornetworks. Antipode 34:111-146. http://dx.doi.org/10.1111/1467-$\underline{8330.00228}$

Catton, Jr., W. R. 1992. Separation versus unification in sociological human ecology. Pages 65-99 in L. Freese, editor. Advances in human ecology. JAI, Greenwich, UK.

Catton, Jr., W. R. 2012. Sociology's neglect of ecological context. Pages 163-174 in D. Erasga, editor. Sociological landscape theories, realities and trends. InTech, Rijeka, Croatia. http://dx. doi.org/10.5772/37977

Chapin, III, F. S., C. Folke, and G. P. Kofinas. 2009. A framework for understanding change. Pages 3-28 in C. Folke, G. P. Kofinas, and F. S. Chapin, III, editors. Principles of ecosystem stewardship. Springer, New York, New York, USA. http://dx.doi. org/10.1007/978-0-387-73033-2 1

Chase-Dunn, C. 2013. Contemporary semiperipheral development: the regimes and the movements. IROWS Working Paper 78. Institute for Research on world systems, Riverside, California, USA. [online] URL: http://irows.ucr.edu/papers/irows78/irows78. $\underline{\text { htm }}$

Chase-Dunn, C., and P. Grimes. 1995. world systems analysis. Annual Review of Sociology 21:387-417. http://dx.doi. org/10.1146/annurev.so.21.080195.002131
Chase-Dunn, C., and K. S. Lawrence. 2010. Alive and well: a response to Sanderson. International Journal of Comparative Sociology 51:470-479. http://dx.doi.org/10.1177/0020715210387983

Cherlet, J. 2010. STS and political ecology in dialogue: future directions for a social study of environmental controversies. Bologna Studies 12:1-22. [online] URL: https://biblio.ugent.be/ record/1062271

Chirot, D., and T. D. Hall. 1982. World-system theory. Annual Review of Sociology 8:81-106. http://dx.doi.org/10.1146/annurev. $\underline{\text { so.08.080182.000501 }}$

Clark, W. C. 2007. Sustainability science: a room of its own. Proceedings of the National Academy of Sciences 104: 1737-1738. http://dx.doi.org/10.1073/pnas.0611291104

Cote, M., and A. J. Nightingale. 2012. Resilience thinking meets social theory: situating social change in socio-ecological systems (SES) research. Progress in Human Geography 36:475-489. http:// dx.doi.org/10.1177/0309132511425708

Crane, T. A. 2010. Of models and meanings: cultural resilience in social-ecological systems. Ecology and Society 15(4): 19. [online] URL: http://www.ecologyandsociety.org/vol15/iss4/ art19/

Cressman, D. 2009. A brief overview of actor-network theory: punctualization, heterogeneous engineering and translation. ACT Lab/Centre for Policy Research on Science and Technology (CPROST), School of Communication, Simon Fraser University, Burnaby, British Columbia, Canada. [online] URL: http://blogs. sfu.ca/departments/cprost/wp-content/uploads/2012/08/0901.pdf.

Cresswell, K. M., A. Worth, and A. Sheikh. 2010. Actor-network theory and its role in understanding the implementation of information technology developments in healthcare. $B M C$ Medical Informatics and Decision Making 10:67. http://dx.doi. org/10.1186/1472-6947-10-67

Crona, B., and K. Hubacek. 2010. The right connections: how do social networks lubricate the machinery of natural resource governance? Ecology and Society 15(4): 18. [online] URL: http:// www.ecologyandsociety.org/vol15/iss4/art18/

Crona, B., A. Wutich, A. Brewis, and M. Gartin. 2013. Perceptions of climate change: linking local and global perceptions through a cultural knowledge approach. Climatic Change 119:519-531. http://dx.doi.org/10.1007/s10584-013-0708-5

Crumley, C. L. 1994. Historical ecology: cultural knowledge and changing landscapes. AltaMira, New York, New York, USA.

Curry, G. N., G. Koczberski, and J. Connell. 2012. Introduction: enacting modernity in the Pacific? Australian Geographer 43:115-125. http://dx.doi.org/10.1080/00049182.2012.682291

Dasgupta, P. 2010. Selected papers of Partha Dasgupta. Volume 1: institutions, innovations, and human values and Volume 2: Poverty, population, and natural resources. Oxford University Press, Oxford.

Davidson, D. J. 2010. The applicability of the concept of resilience to social systems: some sources of optimism and nagging doubts. Society and Natural Resources 23:1135-1149. http://dx.doi. org/10.1080/08941921003652940 
Davidson-Hunt, I., and F. Berkes. 2003. Learning as you journey: Anishinaabe perception of social-ecological environments and adaptive learning. Conservation Ecology 8(1): 5. [online] URL: http://www.consecol.org/vol8/iss1/art5/

Davis, R., and L. Zanotti. 2014. Introduction: hybrid landscapes: science, conservation, and the production of nature. Anthropological Quarterly 87:601-611. http://dx.doi.org/10.1353/ anq.2014.0032

Davoudi, S., K. Shaw, L. J. Haider, A. E. Quinlan, G. D. Peterson, C. Wilkinson, H. Fünfgeld, D. McEvoy, L. Porter, and S. Davoudi. 2012. Resilience: a bridging concept or a dead end? "Reframing" resilience: challenges for planning theory and practice, Interacting traps: resilience assessment of a pasture management system in Northern Afghanistan, Urban resilience: what does it mean in planning practice? Resilience as a useful concept for climate change adaptation? The politics of resilience for planning: a cautionary note. Planning Theory and Practice 13:299-333. http:// dx.doi.org/10.1080/14649357.2012.677124

Deleuze, G., and F. Guattari. 1980. Mille plateaux. Editions de Minuit, Paris, France.

Dolwick, J. S. 2009. 'The social' and beyond: introducing actornetwork theory. Journal of Maritime Archaeology 4:21-49. http:// dx.doi.org/10.1007/s11457-009-9044-3

Dunlap, R. E., and B. K. Marshall. 2007. Environmental sociology. Pages 329-340 in C. D. Bryant and D. L. Peck, editors. 21st Century sociology: a reference handbook. Sage, Thousands Oaks, California, USA.

Dwiartama, A., and C. Rosin. 2014. Exploring agency beyond humans: the compatibility of actor-network theory (ANT) and resilience thinking. Ecology and Society 19(3): 28. http://dx.doi. org/10.5751/ES-06805-190328

Ernstson. H. 2013a. Re-translating nature in post-Apartheid Cape Town: the material semiotics of people and plants at Bottom Road. Actor-network theory for development working paper 4. Centre for Development Informatics, Institute for Development Policy and Management, SED, University of Manchester, Manchester, UK. [online] URL: http://www.stockholmresilience.org/21/ publications/artiklar/8-26-2013-re-translating-nature-in-post-apartheidcape-town-the-material-semiotics-of-people-and-plants-at-bottomroad.html

Ernstson, H. 2013b. The social production of ecosystem services: a framework for studying environmental justice and ecological complexity in urbanized landscapes. Landscape and Urban Planning 109:7-17. http://dx.doi.org/10.1016/j.landurbplan.2012.10.005

Escobar, A. 1996. Constructing nature: elements for a poststructuralist political ecology. Pages 46-68 in R. Peet and M. Watts, editors. Liberation ecologies: environment, development, social movements. Routledge, New York, New York, USA.

Escobar, A. 1998 Whose knowledge, whose nature? Biodiversity, conservation, and the political ecology of social movements. Journal of Political Ecology 5:53-82. [online] URL: ftp://ftp.at. fcen.uba.ar/maestria/ProcesosDeIntervencion/ESCOBAR Whose knowledge, whose nature, the political_ecology of social_movements[1].pdf
Escobar, A. 1999. After nature: steps to an antiessentialist political ecology. Current Anthropology 40:1-30. http://dx.doi. org/10.1086/515799

Evans, J. P. 2011. Resilience, ecology and adaptation in the experimental city. Transactions of the Institute of British Geographers 36: 223-237. http://dx.doi.org/10.1111/ j.1475-5661.2010.00420.x

Evely, A. C., I. Fazey, M. Pinard, and X. Lambin. 2008. The influence of philosophical perspectives in integrative research: a conservation case study in the Cairngorms National Park. Ecology and Society 13(2): 52. [online] URL: http://www. ecologyandsociety.org/vol13/iss2/art52/

Fabinyi, M., L. Evans, and S. J. Foale. 2014. Social-ecological systems, social diversity, and power: insights from anthropology and political ecology. Ecology and Society 19(4): 28. http://dx.doi. org/10.5751/ES-07029-190428

Faik, I., M. Thompson, and G. Walsham. 2013. Facing the dilemmas of development: understanding development action through actor-network theory. Actor-network theory for development Working Paper 2. Centre for Development Informatics, Institute for Development Policy and Management, SED, University of Manchester, Manchester, UK. [online] URL: http://www.cdi.manchester.ac.uk/resources/ant4d/documents/ ANT4DWorkingPaper2FaikEtAl.pdf

Folke, C. 2004. Traditional knowledge in social-ecological systems. Ecology and Society 9(3): 7. [online] URL: http://www. ecologyandsociety.org/vo19/iss3/art7/

Folke, C., S. R. Carpenter, B. Walker, M. Scheffer, T. Chapin, and J. Rockström. 2010. Resilience thinking: integrating resilience, adaptability and transformability. Ecology and Society 15(4): 20. [online] URL: http://www.ecologyandsociety.org/vol15/iss4/ art20/

Folke, C., S. Carpenter, B. Walker, M. Scheffer, T. Elmqvist, L. Gunderson, and C. S. Holling. 2004. Regime shifts, resilience, and biodiversity in ecosystem management. Annual Review of Ecology, Evolution, and Systematics 35:557-581. http://dx.doi. org/10.1146/annurev.ecolsys.35.021103.105711

Folke, C., J. Colding, and F. Berkes. 2003. Synthesis: building resilience and adaptive capacity in social-ecological systems. Pages 352-387 in F. Berkes, J. Colding, and C. Folke, editors. Navigating social-ecological systems: building resilience for complexity and change. Cambridge University Press, Cambridge, UK.

Folke, C., and L. Gunderson. 2010. Resilience and global sustainability. Ecology and Society 15(4): 43. [online] URL: $\underline{\text { http:// }}$ www.ecologyandsociety.org/vol15/iss4/art43/

Folke, C., T. Hahn, P. Olsson, and J. Norberg. 2005. Adaptive governance of social-ecological systems. Annual Review of Environment and Resources 30:441-473. http://dx.doi.org/10.1146/ annurev.energy.30.050504.144511

Forbes, B. C. 2013. Cultural resilience of social-ecological systems in the Nenets and Yamal-Nenets Autonomous Okrugs, Russia: a focus on reindeer nomads of the tundra. Ecology and Society 18 (4): 36. http://dx.doi.org/10.5751/ES-05791-180436 
Forsyth, T. 1996. Science, myth and knowledge: testing Himalayan environmental degradation in Thailand. Geoforum 27:375-392. http://dx.doi.org/10.1016/S0016-7185(96)00020-6

Forsyth, T. 2001. Critical realism and political ecology. Pages 146-154 in A. Stainer and G. Lopez, editors. After postmodernism: critical realism? Athlone Press, London, UK.

Forsyth, T. 2003. Critical political ecology: the politics of environmental science. Routledge, New York, New York, USA.

Forsyth, T. 2008. Political ecology and the epistemology of social justice. Geoforum 39:756-764. http://dx.doi.org/10.1016/j. geoforum.2006.12.005

Forsyth, T., and N. Evans. 2013. What is autonomous adaption? Resource scarcity and smallholder agency in Thailand. World Development 43:56-66. http://dx.doi.org/10.1016/j.worlddev.2012.11.010

Fox, S. 2000. Communities of practice, Foucault and actor network theory. Journal of Management Studies 37:853-867. http://dx.doi.org/10.1111/1467-6486.00207

Gad, C., and C. B. Jensen. 2010. On the consequences of postANT. Science, Technology, and Human Values 35:55-80. http://dx. doi.org/10.1177/0162243908329567

Galaz, V. 2012. Geo-engineering, governance, and socialecological systems: critical issues and joint research needs. Ecology and Society 17(1): 24. http://dx.doi.org/10.5751/ ES-04677-170124

Galaz, V., H. Österblom, Ö. Bodin, and B. Crona. 2014. Global networks and global change-induced tipping points. International Environmental Agreements: Politics, Law and Economics May 2014:1573-1553. http://dx.doi.org/10.1007/s10784-014-9253-6

Gareau, B. J. 2005. We have never been human: agential nature, ANT, and Marxist political ecology. Capitalism Nature Socialism 16:127-140. http://dx.doi.org/10.1080/10455750500376081

Gareau, B. J. 2012. Worlds apart: a social theoretical exploration of local networks, natural actors, and practitioners of rural development in Southern Honduras. Sustainability 4:1596-1618. http://dx.doi.org/10.3390/su4071596

Garud, R., and P. Karnøe. 2003. Bricolage vs. breakthrough: distributed and embedded agency in technology entrepreneurship. Research Policy 32:277-300. http://dx.doi.org/10.1016/S0048-7333 (02)00100-2

Gellert, P. K., and J. Shefner. 2009. People, place and time: how structural fieldwork helps world systems analysis. Journal of world systems Research 2:193-218.

Giddens, A. 1984. The constitution of society: outline of the theory of structuration. University of California Press, Ewing, New Jersey, USA.

Glaser, M. 2006. The social dimension of ecosystem management: strengths and weaknesses of human-nature mind maps. Human Ecology Review 13:122-142. [online] URL: http://www. humanecologyreview.org/pastissues/her132/glaser.pdf

Gömez-Baggethun, E., V. Reyes-García, P. Olsson, and C. Montes. 2012. Traditional ecological knowledge and community resilience to environmental extremes: a case study in Doñana, SW
Spain. Global Environmental Change 22:640-650. http://dx.doi. org/10.1016/j.gloenvcha.2012.02.005

Gotts, N. M. 2007. Resilience, panarchy, and world systems analysis. Ecology and Society 12(1): 24. [online] URL: http://www. ecologyandsociety.org/vol12/iss1/art24/

Granovetter, M. S. 1992. Problems of explanation in economic sociology. Pages 25-56 in N. Nohria and R. G. Eccles, editors. Networks and organizations. Harvard Business School Press, Boston, Massachusetts, USA.

Greenberg, J. B., and T. K. Park. 1994. Political ecology. Journal of Political Ecology 1:1-12. [online] URL: http://jpe.library. arizona.edu/volume 1 /foreword.pdf

Gunderson, L. H., and C. S. Holling. 2002. Panarchy: understanding transformations in human and natural systems. Island, Washington, D.C., USA.

Gunderson, L., C. Folke, and M. Janssen. 2005. Integrating ecology and society to navigate turbulence. Ecology and Society 10(1): 39. [online] URL: http://www.ecologyandsociety.org/ vol10/iss 1/art39/

Gupta, J., and C. Pahl-Wostl. 2013a. Editorial on global water governance. Ecology and Society 18(4): 54. http://dx.doi. org/10.5751/ES-06115-180454

Gupta, J., and C. Pahl-Wostl. 2013b. Global water governance in the context of global and multilevel governance: its need, form, and challenges. Ecology and Society 18(4): 53. http://dx.doi. org/10.5751/ES-05952-180453

Hall, T. D. 2000. A world systems reader: new perspectives on gender, urbanism, cultures, indigenous peoples, and ecology. Rowman and Littlefield, Lanham, Maryland, USA.

Haraway, D. J. 1991. Simians, cyborgs and women: the reinvention of nature. Routledge, New York, New York, USA.

Hatt, K. 2013. Social attractors: a proposal to enhance "resilience thinking" about the social. Society and Natural Resources 26:30-43. http://dx.doi.org/10.1080/08941920.2012.695859

Hayward, B. M. 2013. Rethinking resilience: reflections on the earthquakes in Christchurch, New Zealand, 2010 and 2011. Ecology and Society 18(4): 37. http://dx.doi.org/10.5751/ ES-05947-180437

Hecht, S. B. 1985. Environment, development and politics: capital accumulation and the livestock sector in Eastern Amazonia. World Development 13:663-684. http://dx.doi.org/10.1016/0305-750X (85)90114-7

Heek, R. 2013. Development studies research and actor-network theory. Actor-network theory for development working paper 1. Centre for Development Informatics, Institute for Development Policy and Management, SED, University of Manchester, Manchester, UK. [online] URL: http://www.cdi.manchester.ac. uk/resources/ant4d/documents/ANT4DPaper1Heeks.pdf

Heynen, N. 2014. Urban political ecology I: the urban century. Progress in Human Geography 38:598-604. http://dx.doi. org/10.1177/0309132513500443

Hinchliffe, S. 2007. Geographies of nature: societies, environments, ecologies. Sage, Thousand Oaks, California, USA. 
Holifield, R. 2009. Actor-network theory as a critical approach to environmental justice: a case against synthesis with urban political ecology. Antipode 41:637-658. http://dx.doi.org/10.1111/ j.1467-8330.2009.00692.x

Holling, C. S. 1986. The resilience of terrestrial ecosystems: local surprise and global change. Pages 292-317 in W. C. Clark and R. E. Munn, editors. Sustainable development of the biosphere. Cambridge University Press, London, UK.

Holling, C. S., and L. Gunderson. 2002. Resilience and adaptive cycles. Pages 25-62 in L. Gunderson and C. S. Holling, editors. Panarchy: understanding transformations in human and natural systems. Island, Washington, D.C., USA.

Hornborg, A. 2009. Zero-sum world: challenges in conceptualizing environmental load displacement and ecologically unequal exchange in the world-system. International Journal of Comparative Sociology 50:237-262. http://dx.doi. org/10.1177/0020715209105141

Huntington, E. 1915. Civilization and climate. Yale University Press, New Haven, Connecticut, USA.

Ivakhiv, A. 2002. Toward a multicultural ecology. Organization and Environment 15:389-409. http://dx.doi.org/10.1177/1086026602238169

Jones, N. A., H. Ross, T. Lynam, P. Perez, and A. Leitch. 2011. Mental models: an interdisciplinary synthesis of theory and methods. Ecology and Society 16(1): 46. [online] URL: http:// www.ecologyandsociety.org/vol16/iss1/art46/

Kates, R. W.. From the unity of nature to sustainability science: ideas and practice. CID Working Paper No. 218. Center for International Development, Harvard University, Cambridge, Massachusetts, USA. [online] URL: http://www.hks.harvard. edu/centers/cid/publications/faculty-working-papers/cid-workingpaper-no.-218

Kirsch, S., and D. Mitchell. 2004. The nature of things: dead labor, nonhuman actors, and the persistence of Marxism. Antipode 36:687-705. http://dx.doi.org/10.1111/j.1467-8330.2004.00443.x

Kofinas, G. P. 2009. Adaptive co-management in social-ecological governance. Pages 77-101 in C. Folke, G. P. Kofinas, and F. S. Chapin, III, editors. Principles of ecosystem stewardship: resilience-based natural resource management in a changing world. Springer, New York, New York, USA. http://dx.doi. org/10.1007/978-0-387-73033-2 4

Latour, B. 1987. Science in action: how to follow scientists and engineers through society. Harvard University Press, Cambridge, Massachusetts, USA.

Latour, B. 1993. We have never been modern. Harvard University Press, Cambridge, Massachusetts, USA.

Latour, B. 1996. On actor-network theory: a few clarifications plus more than a few complications. Soziale Welt 47:369-381. [online] URL: http://faculty.georgetown.edu/irvinem/theory/ Latour-clarifications.pdf

Latour, B. 2005. Reassembling the social: an introduction to actornetwork theory. Oxford University Press, Oxford, UK.

Latour, B. and S. Woolgar. 1979. Laboratory life: the social construction of scientific facts. Sage, Thousand Oaks, California, USA.
Law, J. 1990. Technology and heterogeneous engineering: the case of Portuguese expansion. Pages 111-134 in T. J. Pinch, editor. The social construction of technological systems: new directions in the sociology and history of technology. MIT Press, Cambridge, Massachusetts, USA.

Law, J. 1992. Notes on the theory of the actor-network: ordering, strategy, and heterogeneity. Systems Practice 5:379-393. http://dx. doi.org/10.1007/BF01059830

Law, J. 1997.The manager and his powers. Centre for Science Studies, Lancaster University, Lancaster, UK. [online] URL: http://www.lancaster.ac.uk/fass/sociology/research/publications/papers/ law-manager-and-his-powers.pdf

Law, J. 1999. After ANT: complexity, naming and topology. Pages 1-14 in J. Law and J. Hassard, editors. Actor network theory and after. Blackwell, Oxford, UK.

Law, J. 2007. Actor network theory and material semiotics. Centre for Science Studies and Department of Sociology, Lancaster University, Lancaster, UK. [online] URL: http://hwww. heterogeneities.net/publications/Law2007ANTandMaterialSemiotics. pdf

Law, J., and M. Callon. 1988. Engineering and sociology in a military aircraft project: a network analysis of technological change. Social Problems 35:284-297. http://dx.doi.org/10.2307/800623

Law, J., and V. Singleton. 2013. ANT and politics: working in and on the world. Qualitative Sociology 36:485-502. http://dx.doi. org/10.1007/s11133-013-9263-7

Leach, M. 2008, editor. Re-framing resilience: a symposium report. STEPS Working Paper 13. STEPS Centre, Brighton, UK. [online] URL: http://steps-centre.org/publication/re-framing-resiliencetrans-disciplinarity-reflexivity-and-progressive-sustainability- $\% \mathrm{E} 2 \%$ $\underline{\text { 80\%93-a-symposium-report/ }}$

Leach, M., J. Rockström, P. Raskin, I. Scoones, A. C. Stirling, A. Smith, J. Thompson, E. Millstone, A. Ely, E. Arond, C. Folke, and P. Olsson. 2012. Transforming innovation for sustainability. Ecology and Society 17(2): 11. http://dx.doi.org/10.5751/ ES-04933-170211

Leach, M., I. Scoones, and A. Stirling. 2010. Governing epidemics in an age of complexity: narratives, politics and pathways to sustainability. Global Environmental Change 20:369-377. http:// dx.doi.org/10.1016/j.gloenvcha.2009.11.008

Lebel, L., J. M. Anderies, B. Campbell, C. Folke, S. HatfieldDodds, T. P. Hughes, and J. Wilson. 2006. Governance and the capacity to manage resilience in regional social-ecological systems. Ecology and Society 11(1): 19. [online] URL: http://www. ecologyandsociety.org/vol11/iss1/art19/

Lélé, S. 1998. Resilience, sustainability, and environmentalism. Environment and Development Economics 69:1228-1236.

Levin, S., T. Xepapadeas, A.-S. Crépin, J. Norberg, A. de Zeeuw, C. Folke, T. Hughes, K. Arrow, S. Barrett, G. Daily, P. Ehrlich, N. Kautsky, K. G. Mäler, S. Polasky, M. Troell, J. R. Vincent, and B. Walker. 2013. Social-ecological systems as complex adaptive systems: modeling and policy implications. Environment and Development Economics 18:111-132. http://dx.doi.org/10.1017/ $\underline{\mathrm{S} 1355770 \mathrm{X} 12000460}$ 
Long, J., A. Tecle, and B. Burnette. 2003. Cultural foundations for ecological restoration on the White Mountain Apache Reservation. Ecology and Society 8(1): 4. [online] URL: http:// www.ecologyandsociety.org/vol8/iss1/art4/

Lundholm, C., and R. Plummer. 2010. Resilience and learning: a conspectus for environmental education. Environmental Education Research 16:475-491. http://dx.doi.org/10.1080/13504$\underline{622.2010 .505421}$

Lynam, T., R. Mathevet, M. Etienne, S. Stone-Jovicich, A. Leitch, N. Jones, H. Ross, D. Du Toit, S. Pollard, H. Biggs, and P. Perez. 2012. Waypoints on a journey of discovery: mental models in human-environment interactions. Ecology and Society 17(3): 23. http://dx.doi.org/10.5751/ES-05118-170323

Mauro, S. E.-D. 2009. Seeing the local in the global: political ecologies, world systems, and the question of scale. Geoforum 40:116-125. http://dx.doi.org/10.1016/j.geoforum.2008.09.004

McLaughlin, P., and T. Dietz. 2008. Structure, agency and environment: toward an integrated perspective on vulnerability. Global Environmental Change 18:99-111. http://dx.doi.org/10.1016/ j.gloenvcha.2007.05.003

McLean, C., and J. Hassard. 2004. Symmetrical absence/ symmetrical absurdity: critical notes on the production of actornetwork accounts. Journal of Management Studies 41:493-519. http://dx.doi.org/10.1111/j.1467-6486.2004.00442.x

Michon, G. 2011. Revisiting the resilience of chestnut forests in Corsica: from social-ecological systems theory to political ecology. Ecology and Society 16(2): 5. [online] URL: http://www. ecologyandsociety.org/vol16/iss2/art5/

Miettinen, R. 1999. The riddle of things: activity theory and actornetwork theory as approaches to studying innovations. Mind, Culture, and Activity 6:170-195. http://dx.doi.org/10.1080/10749$\underline{039909524725}$

Miller, A. M., and I. Davidson-Hunt. 2013. Agency and resilience: teachings of Pikangikum First Nation elders, northwestern Ontario. Ecology and Society 18(3): 9. http://dx.doi.org/10.5751/ ES-05665-180309

Miller, F., H. Osbahr, E. Boyd, F. Thomalla, S. Bharwani, G. Ziervogel, B. Walker, J. Birkmann, S. van der Leeuw, J. Rockström, J. Hinkel, T. Downing, C. Folke, and D. Nelson. 2010. Resilience and vulnerability: complementary or conflicting concepts? Ecology and Society 15(3): 11. [online] URL: http://www. ecologyandsociety.org/vol15/iss3/art11/

Mol, A. 1999. Ontological politics. A word and some questions. Pages 123-162 in J. Law and J. Hassard, editors. Actor network theory and after. Blackwell, Oxford, UK.

Mol, A. 2002. The body multiple: ontology in medical practice. Duke University Press, Durham, North Carolina, USA. http:// dx.doi.org/10.1215/9780822384151

Mol, A. P. J. 2007. Boundless biofuels? Between environmental sustainability and vulnerability. Sociologia Ruralis 47:297-315. http://dx.doi.org/10.1111/j.1467-9523.2007.00446.x

Mol, A. P. J. 2010. Social theories of environmental reform: towards a third generation. Pages 19-38 in M. Gross and H.
Heinrichs, editors. Environmental sociology: European perspectives and interdisciplinary challenges. Springer, New York, New York, USA. http://dx.doi.org/10.1007/978-90-481-8730-0 2

Moller, H., F. Berkes, P. O. Lyver, and M. Kislalioglu. 2004. Combining science and traditional ecological knowledge: monitoring populations for co-management. Ecology and Society 9(3): 2. [online] URL: http://www.ecologyandsociety.org/vol9/ iss $3 / \mathrm{art} 21$

Moloney, G., Z. Leviston, T. Lynam, J. Price, S. Stone-Jovicich, and D. Blair. 2014. Using social representations theory to make sense of climate change: what scientists and nonscientists in Australia think. Ecology and Society 19(3): 19. http://dx.doi. org/10.5751/ES-06592-190319

Moon, K., and D. Blackman. 2014. A guide to understanding social science research for natural scientists. Conservation Biology 28:1167-1177. http://dx.doi.org/10.1111/cobi.12326

Moore, J. 2011. Ecology, capital, and the nature of our times: accumulation and crisis in the capitalist world-ecology. Journal of world systems Research 17:108-147. [online] URL: http://www. jasonwmoore.com/uploads/Moore Ecology_Capital_and the Origins of Our Times JWSR 2011.pdf

Moore, M.-L., and F. Westley. 2011. Surmountable chasms: networks and social innovation for resilient systems. Ecology and Society 16(1): 5. [online] URL: http://www.ecologyandsociety. org/voll6/iss1/art5/

Muldavin, J. 2008. The time and place for political ecology: an introduction to the articles honoring the life-work of Piers Blaikie. Geoforum 39:687-697. http://dx.doi.org/10.1016/j.geoforum.2007.07.003

Nadasdy, P. 2007. Adaptive co-management and the gospel of resilience. Pages 208-227 in D. Armitage, F. Berkes, and N. Doubleday, editors. Adaptive co-management: collaboration, learning, and multi-level governance. University of British Columbia Press, Vancouver, British Columbia, Canada.

Nauser, M., and D. Steiner. 1993. Human ecology: fragments of anti-fragmentary views of the world. Routledge, New York, New York, USA. http://dx.doi.org/10.4324/9780203414989

Navarro, V. 1982. The limits of the world systems theory in defining capitalist and socialist formations. Science and Society 46:77-90.

Nelson, D. R., W. N. Adger, and K. Brown. 2007. Adaptation to environmental change: contributions of a resilience framework. Annual Review of Environment and Resources 32:395-419. http:// dx.doi.org/10.1146/annurev.energy.32.051807.090348

Nightingale, A. J. 2002. Can social theory adequately address nature-society issues? Do political ecology and science studies in geography incorporate ecological change? Third International Critical Geography Conference, Békéscsaba, Hungary, June 25-30, 2002. [online] URL: https://www.era.lib.ed.ac.uk/ handle/1842/1437

Nimmo, R. 2011. Actor-network theory and methodology: social research in a more-than-human world. Methodological Innovations Online 63:108-119. [online] URL: http://www. methodologicalinnovations.org.uk/wp-content/uploads/2013/11/ MIO63Paper33.pdf 
Norgaard, R. B. 1984. Coevolutionary agricultural development. Economic Development and Cultural Change 32:525-546. http:// dx.doi.org/10.1086/451404

Norgaard, R. B. 2010. Ecosystem services: from eye-opening methaphor to complexity blinder. Ecological Economics 69:1219-1227. http://dx.doi.org/10.1016/j.ecolecon.2009.11.009

O’Connor, J. 1997. Natural causes: essays in ecological Marxism. Guilford, New York, New York, USA.

Ogden, L. A. 2011. Swamplife: people, gators, and mangroves entangled in the Everglades. University of Minnesota Press, Minneapolis, Minnesota, USA.

Ogden, L., N. Heynen, U. Oslender, P. West, K.-A. Kassam, and P. Robbins. 2013. Global assemblages, resilience, and Earth stewardship in the Anthropocene. Frontiers in Ecology and the Environment 11:341-347. http://dx.doi.org/10.1890/120327

Olsson, P., L. H. Gunderson, S. R. Carpenter, P. Ryan, L. Lebel, C. Folke, and C. S. Holling. 2006. Shooting the rapids: navigating transitions to adaptive governance of social-ecological systems. Ecology and Society 11(1): 18. [online] URL: http://www. ecologyandsociety.org/vol11/iss1/art18/

Ostrom, E. 1990. Governing the commons: the evolution of institutions for collective action. Cambridge University Press, Cambridge, UK. http://dx.doi.org/10.1017/CBO9780511807763

Pahl-Wostl, C., G. Becker, C. Knieper, and J. Sendzimir. 2013. How multilevel societal learning processes facilitate transformative change: a comparative case study analysis on flood management. Ecology and Society 18(4): 58. http://dx.doi.org/10.5751/ ES-05779-180458

Peterson, G. 2000. Political ecology and ecological resilience: an integration of human and ecological dynamics. Ecological Economics 35:323-336. http://dx.doi.org/10.1016/S0921-8009(00) 00217-2

Peterson, G., and A. Hornborg. 2012. Grasping sustainability: a debate on resilience theory versus political ecology. Video. Centre for Sustainable Development, CDS Uppsala, Uppsala University, Uppsala, Sweden. [online] URL: http://www.csduppsala.uu. se/2012/video-and-slides-from-grasping-sustainability/

Phelan, L., A. Henderson-Sellers, and R. Taplin. 2012. The political economy of addressing the climate crisis in the Earth system: undermining perverse resilience. New Political Economy 18:198-226. http://dx.doi.org/10.1080/13563467.2012.678820

Plummer, R., and D. Armitage. 2007. A resilience-based framework for evaluating adaptive co-management: linking ecology, economics and society in a complex world. Ecological Economics 61:62-74. http://dx.doi.org/10.1016/j.ecolecon.2006.09.025

Porter, L., and S. Davoudi. 2012. The politics of resilience for planning: a cautionary note. Planning Theory and Practice 13:329-333.

Prew, P. 2003. The $21^{\text {st }}$ century world-ecosystem: systematic collapse or transition to a new dissipative structure? Pages 203-219 in W. A. Dunaway, editor. Emerging issues in the 21st century world-system: new theoretical directions for the 21 st century world systems. Praeger, Westport, Connecticut, USA.
Radder, H. 1992. Normative reflexions on constructivist approaches to science and technology. Social Studies of Science 22:141-173. http://dx.doi.org/10.1177/0306312792022001009

Rammert, W. 2008. Where the action is: distributed agency between humans, machines, and programs. Technology Studies working paper, TUTS-WP-4-2008. Technische Universität, Berlin, Germany. [online] URL: https://www.ts.tu-berlin.de/fileadmin/ fg226/TUTS/TUTS WP 4 2008.pdf

Rathwell, K. J., and G. D. Peterson. 2012. Connecting social networks with ecosystem services for watershed governance: a social-ecological network perspective highlights the critical role of bridging organizations. Ecology and Society 17(2): 24. http:// dx.doi.org/10.5751/ES-04810-170224

Ratner, B. D., P. Cohen, B. Barman, K. Mam, J. Nagoli, and E. H. Allison. 2013. Governance of aquatic agricultural systems: analyzing representation, power, and accountability. Ecology and Society 18(4): 59. http://dx.doi.org/10.5751/ES-06043-180459

Resilience Alliance. 2011. Assessing resilience in social-ecological systems: workbook for practitioners. Version 2.0. Resilience Alliance. [online] URL: http://www.resalliance.org/3871.php

Reyes-García, V., L. Aceituno-Mata, L. Calvet-Mir, T. Garnatje, E. Gömez-Baggethun, J. J. Lastra, R. Ontillera, M. Parada, M. Rigat, J. Vallès, S. Vila, and M. Pardo-de-Santayana. 2014. Resilience of traditional knowledge systems: the case of agricultural knowledge in home gardens of the Iberian Peninsula. Global Environmental Change 24:223-231 http://dx.doi. org/10.1016/j.gloenvcha.2013.11.022

Roberts, J. M. 2012. Poststructuralism against poststructuralism: actor-network theory, organizations and economic markets. European Journal of Social Theory 15:35-53. http://dx.doi. org/10.1177/1368431011423573

Robbins, P. 2004. Political ecology: a critical introduction. Blackwell, Oxford, UK.

Rocheleau, D. E. 2008. Political ecology in the key of policy: from chains of explanation to webs of relation. Geoforum 39:716-727. http://dx.doi.org/10.1016/j.geoforum.2007.02.005

Rockström, J., W. Steffen, K. Noone, Å. Persson, F. S. Chapin, III, E. F. Lambin, T. M. Lenton, M. Scheffer, C. Folke, H. J. Schellnhuber, B. Nykvist, C. A. de Wit, T. Hughes, S. van der Leeuw, H. Rodhe, S. Sörlin, P. K. Snyder, R. Costanza, U. Svedin, M. Falkenmark, L. Karlberg, R. W. Corell, V. J. Fabry, J. Hansen, B. Walker, D. Liverman, K. Richardson, P. Crutzen, and J. A. Foley. 2009a. A safe operating space for humanity. Nature 461:472-475. http://dx.doi.org/10.1038/461472a

Rockström, J., W. Steffen, K. Noone, Å. Persson, F. S. Chapin, III, E. Lambin, T. M. Lenton, M. Scheffer, C. Folke, H. Schellnhuber, B. Nykvist, C. A. de Wit, T. Hughes, S. van der Leeuw, H. Rodhe, S. Sörlin, P. K. Snyder, R. Costanza, U. Svedin, M. Falkenmark, L. Karlberg, R. W. Corell, V. J. Fabry, J. Hansen, B. Walker, D. Liverman, K. Richardson, P. Crutzen, and J. Foley. $2009 \mathrm{~b}$. Planetary boundaries: exploring the safe operating space for humanity. Ecology and Society 14(2): 32. [online] URL: http:// www.ecologyandsociety.org/vol14/iss2/art32/ 
Rogers, R., and N. Marres. 2002 French scandals on the Web, and on the streets: a small experiment in stretching the limits of reported reality. Asian Journal of Social Science 30:339-353 http:// dx.doi.org/10.1163/156853102320405898

Roux, D. J., K. Murray, J. L. Nel, L. Hill, H. Roux, and A. Driver. 2011. From scorecard to social learning: a reflective coassessment approach for promoting multiagency cooperation in natural resource management. Ecology and Society 16(1): 24. [online] URL: http://www.ecologyandsociety.org/vol16/iss1/art24/

Rudy, A. P., and D. White. 2013. Hybridity. Pages 121-132 in C. Death, editor. Critical environmental politics. Routledge, New York, New York, USA.

Ruming, K. 2008. Negotiating development control: using actornetwork theory to explore the creation of residential building policy. City Futures Research Centre, Faculty of the Built Environment, University of New South Wales, Sydney, Australia. [online] URL: http://149.171.158.96/sites/default/files/upload/negotiatingdevelopmentcontrol.pdf

Ruiz-Mallén, I., and E. Corbera. 2013. Community-based conservation and traditional ecological knowledge: implications for social-ecological resilience. Ecology and Society 18(4): 12. http://dx.doi.org/10.5751/ES-05867-180412

Rydin, Y. 2013. Using actor-network theory to understand planning practice: exploring relationships between actants in regulating low-carbon commercial development. Planning Theory 12:23-45. http://dx.doi.org/10.1177/1473095212455494

Sayes, E. M. 2014. Actor-network theory and methodology: just what does it mean to say that nonhumans have agency? Social Studies of Science 44:134-149. http://dx.doi.org/10.1177/030631$\underline{2713511867}$

Scott-Smith, T. 2013. The least provocative path: an ANT lens on development project formation and dissolution. Actor-network theory for development working paper 3. Centre for Development Informatics, Institute for Development Policy and Management, SED, University of Manchester, Manchester, UK. [online] URL: http://www.rsc.ox.ac.uk/publications/the-least-provocative-pathan-ant-lens-on-development-project-formation-and-dissolution

Sen, A. 2004. Development as capability expansion. Pages in $\mathrm{S}$. Fukuda-Parr and A. K. S. Kumar, editors. Readings in human development: concepts, measures and policies for a development paradigm. Oxford University Press, Oxford, UK.

Sewell, Jr., W. H. 1992. A theory of structure: duality, agency, and transformation. American Journal of Sociology 98:1-29. http://dx. doi.org/10.1086/229967

Shaw, K. 2012. "Reframing" resilience: challenges for planning theory and practice. Planning Theory and Practice 13(2):308-312.

Sheehan, R., and J. M. Vadjunec. 2012. Placing community through actor-network theory in Oklahoma's 'no man's land'. Social and Cultural Geography 13:915-936. http://dx.doi. org/10.1080/14649365.2012.728616

Simmie, J., and R. Martin. 2010. The economic resilience of regions: towards an evolutionary approach. Cambridge Journal of Regions, Economy and Society 3:27-43 http://dx.doi. org/10.1093/cjres/rsp029
Smith, A., and A. Stirling. 2010. The politics of social-ecological resilience and sustainable socio-technical transitions. Ecology and Society 15(1): 11. [online] URL: http://www.ecologyandsociety. org/vol15/iss1/art11/

Spinks, M. 2011. Adoption of a network approach to sustainable building standard process, not product: a response column to "a political-ecology of the built environment: LEED certification for green buildings", Cidell, 2009. Local Environment, 14(7), pp. 621-633. Local Environment 16:87-92. http://dx.doi. org/10.1080/13549839.2010.541232

Stanforth, C. 2006. Using actor-network theory to analyze egovernment implementation in developing countries. Information Technologies and International Development 3:35-60.

Stephenson, Jr., M. O. 2011. Considering the relationships among social conflict, social imaginaries, resilience, and communitybased organization leadership. Ecology and Society 16(1): 34. [online] URL: http://www.ecologyandsociety.org/voll6/iss1/ $\underline{\operatorname{art} 34 /}$

Stone-Jovicich, S. S., T. Lynam, A. Leitch, and N. A. Jones. 2011. Using consensus analysis to assess mental models about water use and management in the Crocodile River Catchment, South Africa. Ecology and Society 16(1): 45. [online] URL: http://www. ecologyandsociety.org/vol16/iss1/art45/

Stott, P. 1999. Tropical rainforests: a political ecology of hegemonic myth making. Institute of Economic Affairs, London, UK. [online] URL: http://www.luxurylite.com/RainForest.pdf

Strang, V. 2005. Common senses: water, sensory experience and the generation of meaning. Journal of Material Culture 10:92-120. http://dx.doi.org/10.1177/1359183505050096

Strang, V. 2006. Fluidscapes: water, identity and the senses. Worldviews: Global Religions, Culture, and Ecology 10:147-154. http://dx.doi.org/10.1163/156853506777965802

Strang, V. 2011a. Conceptual relations: water, ideologies and theoretical subversions. Pages 185-211 in C. Chen, J. Macleod, and A. Neimanis, editors. Thinking with water. McGill-Queens University Press, Montreal, Quebec, Canada.

Strang, V. 2011b. Elusive forms: materiality and cultural diversity in the ownership of water. Pages 195-218 in D. Grinlinton and P. Taylor, editors. Property rights and sustainability: the evolution of property rights to meet ecological challenges. Brill, Leiden. The Netherlands.

Trosper, R. L. 2005. Emergence unites ecology and society. Ecology and Society 10(1): 14. [online] URL: http://www. ecologyandsociety.org/vol10/iss1/art14/

Turner, II, B. L. 1997. Spirals, bridges and tunnels: engaging human-environment perspectives in geography. Ecumene 4:196-217.

Turner, II, B. L. 2008. A skeptic's comments on resilience and alternative approaches to coupled human-environment systems. Pages 9-10 in M. Leach, editor. Re-framing resilience: a symposium report. STEPS Working Paper 13. STEPS Centre, Brighton, UK.

Turner, II, B. L. 2010. Vulnerability and resilience: coalescing or paralleling approaches for sustainability science? Global 
Environmental Change 20:570-576. http://dx.doi.org/10.1016/j. gloenvcha.2010.07.003

Turner, II, B. L., E. F. Lambin, and A. Reenberg. 2007. The emergence of land change science for global environmental change and sustainability. Proceedings of the National Academy of Sciences 104:20666-20671. http://dx.doi.org/10.1073/pnas.0704119104

Turner, II, B. L., P. A. Matson, J. J. McCarthy, R. W. Corell, L. Christensen, N. Eckley, G. Hovelsrud-Broda, J. X. Kasperson, R. E. Kasperson, A. Luers, M. L. Martello, S. Mathiesen, C. Polsky, A. Pulsipher, A. Schiller, and N. Tyler. 2003. Illustrating the coupled human-environment system for vulnerability analysis: three case studies. Proceedings of the National Academy of Sciences 100:8080-8085. http://dx.doi.org/10.1073/pnas.1231334100

Turner, II, B. L., and P. Robbins. 2008. Land-change science and political ecology: similarities, differences, and implications for sustainability science. Annual Review of Environment and Resources 33:295-316. http://dx.doi.org/10.1146/annurev. environ.33.022207.104943

Turner, M. 1993. Overstocking the range: a critial analysis of the environmental science of Sahelian pastoralism. Economic Geography 69:402-421. http://dx.doi.org/10.2307/143597

Turner, M. D. 2014. Political ecology I: an alliance with resilience? Progress in Human Geography 38:616-623. http://dx.doi. org/10.1177/0309132513502770

Urry, J. 2000. Sociology beyond societies: mobilities for the twentyfirst century. Routledge, New York, New York, USA.

Urry, J. 2005. The complexities of the global. Theory, Culture and Society 22:235-254.

van der Duim, R. 2005. Tourismscapes: an actor-network perspective on sustainable development. Dissertation, Wageningen University, Wageningen, The Netherlands. [online] URL: http:// www.academia.edu/3210262/Tourismscapes_An_actornetwork perspective on sustainable tourism development

van der Duim, R. 2007. Tourismscapes an actor-network perspective. Annals of Tourism Research 34:961-976. http://dx. doi.org/10.1016/j.annals.2007.05.008

Vayda, A. P., and B. B. Walters. 1999. Against political ecology. Human Ecology 27:167-179. http://dx.doi.org/10.1023/A:1018713502547

Venturini, T., and B. Latour. 2010. The social fabric: digital traces and quali-quantitative methods. Pages 87-104 in Proceedings of futur en Seine 2009. Cap Digital, Paris, France.

Venturini, T., and D. Guido. 2012. Once upon a text: an ANT tale in text analysis. Sociologica 3. [online] URL: http://www. medialab.sciences-po.fr/publications/Venturini_Guido-

Once Upon A Text.pdf

Vink, M. J., A. Dewulf, and C. Termeer. 2013. The role of knowledge and power in climate change adaptation governance: a systematic literature review. Ecology and Society 18(4): 40. http:// dx.doi.org/10.5751/ES-05897-180446

Walker, P. A. 2005. Political ecology: where is the ecology? Progress in Human Geography 29:73-82. http://dx.doi. org/10.1191/0309132505ph530pr
Walker, B. H., S. R. Carpenter, J. Rockström, A.-S. Crépin, and G. D. Peterson. 2012. Drivers, "slow" variables, "fast" variables, shocks, and resilience. Ecology and Society 17(3): 30. http://dx. doi.org/10.5751/ES-05063-170330

Walker, B., and D. Salt. 2006. Resilience thinking: sustaining ecosystems and people in a changing world. Island, Washington, D.C., USA.

Walker, B., and D. Salt. 2012. Resilience practice: building capacity to absorb disturbance and maintain function. Island, Washington, D.C., USA. http://dx.doi.org/10.5822/978-1-61091-231-0

Wallerstein, I. 1974. The modern world system I: capitalist agriculture and the origins of the European world-economy in the sixteenth century. Academic, New York, New York, USA.

Wallerstein, I. 2000. The essential Wallerstein. New Press, New York, New York, USA.

Walsh, F. J., P. V. Dobson, and J. C. Douglas. 2013. Anpernirrentye: a framework for enhanced application of indigenous ecological knowledge in natural resource management. Ecology and Society 18(3): 18. http://dx.doi. org/10.5751/ES-05501-180318

Watts, M. J. 1985. Social theory and environmental degradation: the case of Sudano-Sahelian West Africa. Pages 14-32 in Y. Gradus, editor. Desert development: man and technology in sparselands. D. Reidel, Dordrecht, The Netherlands.

West, S., L. J. Haider, H. Sinare, and T. Karpouzoglou. 2014. Beyond divides: prospects for synergy between resilience and pathways approaches to sustainability. STEPS Working Paper 65. STEPS Centre, Brighton, UK. [online] URL: http://steps-centre. org/publication/resilience-pathways/

Westley, F. 2013. Social innovation and resilience: how one enhances the other. Stanford Social Innovation Review. Sponsored supplement to SSIR. Summer 2013.

Westley, F., S. R. Carpenter, W. A. Brock, C. S. Holling, and L. H. Gunderson. 2002. Why systems of people and nature are not just social and ecological systems. Pages 103-120 in L. H. Gunderson, and C. S. Holling, editors. Panarchy: understanding transformations in systems of humans and nature. Island, Washington, D.C., USA.

Westley, F. R., O. Tjornbo, L. Schultz, P. Olsson, C. Folke, B. Crona, and Ö. Bodin. 2013. A theory of transformative agency in linked social-ecological systems. Ecology and Society 18(3): 27. http://dx.doi.org/10.5751/ES-05072-180327

Whatmore, S. J. 2002. Hybrid geographies: natures, cultures, spaces. Sage, Thousand Oakes, California, USA.

Whatmore, S. J. 2008. Materialist returns: practising cultural geography in and for a more-than-human world. Pages 481-490 in N. C. Johnson, editor. Culture and society: critical essays in human geography. Ashgate, Burlington, Vermont, USA.

Whatmore, S. J. 2013. Where natural and social science meet? Reflections on an experiment in geographical practice. Pages 161-177 in A. Barry and G. Born, editors. Interdisciplinarity: reconfigurations of the social and natural sciences. Routledge, New York, New York, USA. 
White, D. R. 1998. Postmodern ecology: communication, evolution, and play. State University of New York Press, Albany, New York, USA.

White, D. F. 2006. A political sociology of socionatures: revisionist manoeuvres in environmental sociology. Environmental Politics 15:59-77. http://dx.doi.org/10.1080/09644010500418738

Widgren, M. 2012. Resilience thinking versus political ecology: understanding the dynamics of small-scale labour-intensive farming landscapes. Pages 95-110 in T. Plieninger and C. Bieling, editors. Resilience and the cultural landscape: understanding and managing change in human-shaped environments. Cambridge University Press, Cambridge, UK. http://dx.doi.org/10.1017/ CBO9781139107778.008

Woodgate, G., and M. Redclift. 1998. From a 'sociology of nature' to environmental sociology: beyond social construction. Environmental Values 7:3-24. http://dx.doi.org/10.3197/0963271$\underline{98129341447}$

Yonay, Y. P. 1994. When black boxes clash: competing ideas of what science is in economics, 1924-39. Social Studies of Science 24:39-80. http://dx.doi.org/10.1177/030631279402400103

Young, O. R., F. Berkhout, G. C. Gallopin, M. A. Janssen, E. Ostrom, and S. van der Leeuw. 2006. The globalization of socioecological systems: an agenda for scientific research. Global Environmental Change 16:304-316. http://dx.doi.org/10.1016/j. gloenvcha.2006.03.004

Zimmerer, K. S. 2000. The reworking of conservation geographies: nonequilibrium landscape and nature-society hybrids. Annals of the Association of American Geographers 90:356-369. http://dx.doi.org/10.1111/0004-5608.00199

Zimmerer, K. S. 2003. Future directions in political ecology: nature-society fusions and scales of interaction. Pages 274-295 in K. S. Zimmerer and T. J. Bassett, editors. Political ecology: an integrative approach to geography and environment-development studies. Guilford, New York, New York, USA.

Zimmerer, K. S. 2010. Biological diversity in agriculture and global change. Annual Review of Environment and Resources 35:137-166. http://dx.doi.org/10.1146/annurev-environ-040309-113840

Zimmerer, K. S. 2011. The landscape technology of spate irrigation amid development changes: assembling the links to resources, livelihoods, and agrobiodiversity-food in the Bolivian Andes. Global Environmental Change 21:917-934. http://dx.doi. org/10.1016/j.gloenvcha.2011.04.002

Zimmerer, K. S., and T. J. Bassett. 2003. Future directions in political ecology: nature-society fusions and scales of interaction. Pages 274-295 in K. S. Zimmerer and T. J. Bassett, editors. Political ecology: an integrative approach to geography and environmentdevelopment studies. Guilford, New York, New York, USA. 